\title{
LAS PENAS DE ENCIERRO PERPETUO DESDE UNA PERSPECTIVA HISTÓRICA
}

\author{
Tàlia GonZÁLez Collantes \\ Doctora en Derecho y Licenciada en Criminología \\ Acreditada como Profesora Contratada Doctora \\ Departamento de Derecho Penal. Facultad de Derecho \\ Universitat de València \\ talia.gonzalez@uv.es
}

\section{RESUMEN}

Son pocos los trabajos publicados sobre la historia de las penas privativas de libertad, por lo cual llevo un tiempo dedicada a intentar llenar este vacío. En esta ocasión he querido explicar cuál ha sido el desarrollo de las sanciones de encierro perpetuo en los sucesivos Códigos Penales españoles, poniendo énfasis en el contexto político en el que se aprueban estos Códigos y las reformas de los mismos, así como también en las teorías de la pena y en las razones político-criminales que han contribuido a su justificación o crítica.

Palabras clave: encierro perpetuo, evolución, regulación, fines de la pena, política criminal.

\section{ABSTRACT}

Studies about the history of imprisonment sentences are scarce, so I have devoted myself to fill in such gap. This time I mean to explain the follow up of life imprisonment in the various Spanish Penal Codes, making emphasis on the political context in which such Codes were approved as well as on their several reforms and also on theories of punishment and criminal political reasons for its existence or criticism. Keywords: Life imprisonment, development, regulation, aims of punishment, criminal policy.

\section{ZUSAMMENFASSUNG}

Es gibt nur wenige veröffentliche Arbeiten, die sich mit der Geschichte der Freiheitsstrafen auseinandersetzen, daher habe ich vor einiger Zeit damit begonnen, an der Schließung dieser Lücke zu arbeiten. Im vorliegenden Fall babe ich die Entwicklung der lebenslänglichen Haftstrafen in den aufeinanderfolgenden spanischen Strafgesetzbüchern aufzeigen wollen. Hierbei habe ich das Augenmerk auf den jeweiligen politischen Kontext gelegt, in welchem diese Strafgesetzbücher erlassen beziehungsweise reformiert wurden. Ebenso babe ich den Schwerpunkt auf die Straftheorien und die politisch-kriminalistischen Ursachen gelegt, die zur Rechtfertiung oder Kritik der Strafen beigetragen haben.

Schlüsselwörter: Lebenslängliche Haft, Entwicklung, Regulation, Strafabsichten, Kriminalpolitik. 
SUMARIO: I. INTRODUCCIÓN.-II. LAS PENAS DE ENCIERRO PERPETUO EN LOS CÓDIGOS DECIMONÓNICOS.-1. El Código Penal de 1822.2. El Código Penal de 1848.—3. El Código Penal de 1870.--III. LAS PENAS DE ENCIERRO PERPETUO EN LOS CÓDIGOS PENALES DEL SIGLO XX.1. El Código Penal de 1928.-2. El Código Penal de 1931._3. El Código Penal de 1944.-IV. LAS PENAS DE ENCIERRO PERPETUO EN EL CÓDIGO PENAL DE 1995.-1. La inclusión de manera encubierta de la pena de prisión perpetua.-2. La inclusión de manera explícita de la pena de prisión perpetua.V. REFLEXIÓN FINAL: EL POR QUE DEL RESTABLECIMIENTO DE LA PENA DE PRISIÓN PERPETUA.-VI. BIBLIOGRAFÍA.

\section{INTRODUCCIÓN}

El presente artículo tiene por objeto ofrecer una perspectiva histórica de la pena de encierro perpetuo. Más concretamente se analiza su evolución en el marco legal jurídico-penal español desde la aprobación del Código de 1822 hasta la Ley Orgánica 1/2015, de 30 de marzo, de reforma de la Ley Orgánica 10/1995, de 23 de noviembre, del Código Penal. Y ello se hará teniendo en cuenta el contexto político en el que se han aprobado los sucesivos Códigos y sus reformas, así como también las teorías de la pena y razones político-criminales que han contribuido a la justificación o crítica de la sanción en cuestión.

Podemos encontrar algunos antecedentes de la penalidad indicada en la legislación castellana del antiguo régimen, pues en el Fuero Real, otorgado en 1255 por Alfonso X, se preveía imponer la pena de reclusión en orden religiosa o monasterio a los hombres que tenían relaciones con familiares y cuñadas para que hiciesen penitencia perpetuamente, o hasta que el monarca ordenase ${ }^{1}$. Incluso con anterioridad se recurrió a la misma, pues se sabe que en época clásica los romanos en alguna ocasión permutaron la pena de muerte por la de encierro de por vida ${ }^{2}$ y que en algún caso aislado se impuso como pena principal, como una vez que el Senado condenó a una persona a acabar sus días privado de libertad en una prisión por haberse cortado los dedos de la mano izquierda para de esta manera evitar ir a la guerra ${ }^{3}$. Pero fue a partir de la etapa codifi-

${ }^{1}$ Fuero Real, libro IV, título VIII, Ley $1 .{ }^{\mathrm{a}}$

2 Véanse T. Mommsen, El Derecho penal romano, vol. II, traducción al castellano de P. Dorado Montero, Madrid, Jiménez Gil Editor, 1999, p. 361; L. GarRIDo GuZMÁn, Manual de ciencia penitenciaria, Madrid, Edersa, 1983, p. 75; A. Téllez Aguilera, Los sistemas penitenciarios y sus prisiones. Derecho y realidad, Madrid, Edisofer, 1998, p. 28, y S. LEGANÉs GÓMEZ, La evolución de la clasificación penitenciaria, Madrid, Ministerio del Interior, 2005, p. 18.

3 Véanse A. Moro Rodríguez, «La prisión en la Roma antigua», Revista de la Escuela 
cadora cuando empezó a recurrirse a la pena en cuestión no como simple excepción, por ello que se partirá de este periodo y se analizarán los diferentes Códigos Penales. Afortunadamente con el tiempo se apostará por su abolición, aunque hay que lamentar que hace escasos meses se ha optado por su readmisión.

Como veremos a continuación, en la historia de la pena a analizar cabe diferenciar tres etapas. En la primera etapa se recurre a ella con demasiada frecuencia, por razones de utilidad, por creerse que resulta efectiva en la reducción de la criminalidad, más incluso que la pena de muerte, cuyo campo de aplicación permite reducir. En la segunda etapa se prescindirá de ella, primero recurriendo al indulto de los condenados y después haciéndola desaparecer del catálogo punitivo, por ser contraria a la finalidad resocializadora de la pena y a la propia dignidad humana. Y en la tercera etapa se opta, a pesar de todo, por recuperarla. A pesar de decirse que se trata de una pena revisable, no se cierra la puerta a que la privación de libertad acabe con la muerte del reo. Lejos de ser una legislación penal razonada, la actual se ha creado a partir del alarmismo social producido por el efecto expansivo que la opinión pública tiene ante determinados hechos delictivos. Se ha producido durante los últimos años un endurecimiento progresivo del castigo que se ha llevado hasta el último extremo y que no responde a un incremento considerable de la delincuencia ni ha redundado en un descenso significativo de la misma, sino únicamente en un asombroso crecimiento de la población penitenciaria, así como también del gasto público destinado a su mantenimiento. Sin embargo, satisface a la sociedad, alimenta sus ansias punitivas. Si continúa esta tendencia lo próximo que veremos es que se exija que el preso después de muerto continúe en la cárcel.

\section{LAS PENAS DE ENCIERRO PERPETUO EN LOS CÓDIGOS DECIMONÓNICOS}

\section{El Código Penal de 1822}

Las primeras cuestiones de las que se ocuparon las Cortes de Cádiz de 1810 se referían en múltiples ocasiones a los problemas penales y peniten-

de Estudios Penitenciarios, núm. 19 (1946), p. 591, y A. Téllez Aguilera, Los sistemas penitenciarios y sus prisiones..., op. cit., p. 28. 
ciarios, preocupación que era general en la época. La ruptura con el régimen anterior requería, además de la aprobación de una Constitución, la formación de un Código Penal adaptado a los principios rectores de ésta. Sin embargo, a pesar de que en la Constitución aprobada en 1812 se anunciaba la promulgación de un Código $\mathrm{Penal}^{4}$, la restauración del absolutismo por Fernando VII frustró cualquier iniciativa, hasta que después de la sublevación de Riego de 1820, durante el denominado Trienio Liberal, para ser exactos en 1822, se aprobó, por fin, dicho texto legal.

El que este Código fuera el primero basado en las ideas de la Ilustración no constituyó un obstáculo para que incluyese una pena tan cruel como la de trabajos perpetuos ${ }^{5}$, la cual seguía en gravedad a la de muerte, y, además de que se imponía junto a la accesoria de infamia ${ }^{6}$, llevaba aparejadas tanto la privación de libertad como la obligación de trabajar de los condenados, quienes tenían que hacerlo atados a una cadena y en las labores más duras y penosas del establecimiento ${ }^{7}$. Debe tenerse en cuenta que así como los ilustrados, o muchos de ellos, se opusieron a la pena capital, defendieron la de privación de libertad de por vida. La mayoría izaron la bandera de la prevención general negativa y a favor de esta sanción decían que se trataba de una medida de castigo eficaz para intimidar, para causar al grueso de la población la mayor impresión posible, más incluso que la pena de muerte, porque los ciudadanos la tienen presente durante mucho tiempo, aparte de que permitía restringir la aplicación de la pena capital, en crisis en prácticamente toda Europa. En palabras de Von Henting: «La pena privativa de libertad fue el nuevo gran invento social, intimidando siempre, corrigiendo a menudo, que tenía que hacer retroceder el delito, o derrotarlo, en todo caso encerrarlo entre muros. La crisis de la pena de muerte encontró así su fin, porque un método mejor y más eficaz, excepción hecha de pocos de los casos más graves, ocupaba su lugar» ${ }^{8}$.

A ello hay que sumar, por otra parte, en lo relativo al trabajo forzado que la pena aquí analizada llevaba implícito, que fue ensalzado por los hombres de la Ilustración. Por ejemplo, el benedictino Sarmiento, uno de los primeros españoles en alzar la voz en contra de la pena de muerte, en 1764, mucho antes de aprobarse el primer Código Penal español, propu-

${ }^{4}$ Art. 258 de la Constitución de Cádiz de 1812.

Art. 28 del Código Penal de 1822.

Art. 30 del Código Penal de 1822.

Art. 47 del Código Penal de 1822.

${ }^{8}$ H. Von Hentig, La pena II, las formas modernas de aparición, traducción al castellano y notas de J. M. ${ }^{a}$ Rodríguez DevesA, Madrid, Espasa Calpe, 1968, p. 186. 
so que en su lugar se separase a los delincuentes de la sociedad, que se les encerrarse en un lugar donde se les pudiese obligar a trabajar, ya que así, vivos, serían más útiles a la sociedad ${ }^{9}$. Como bien apuntó Foucault, desde la formulación de las teorías del pacto social el derecho de castigar se trasladó de la venganza del soberano a la defensa de la sociedad, el delincuente dejó de ser un enemigo del rey para convertirse en un enemigo de la sociedad entera, y el cuerpo del condenado dejó de ser una cosa del monarca, sobre la cual éste imprimía su marca y dejaba caer los efectos de su poder, para convertirse en un bien social, objeto de una apropiación colectiva y útil ${ }^{10}$.

No obstante, en el Código Penal de 1822 se realizó un intento conciliador de diversos fines de la pena no existente en las legislaciones contemporáneas. A pesar de que la prevención general negativa era la que predominaba ${ }^{11}$, también se le daba mucha importancia a la regeneración del delincuente, a su corrección ${ }^{12}$, a lo que contribuyó la tradición senequista y cristiana. Tanto es así que se preveía que, en caso de darse muestras de arrepentimiento y enmienda, se pudiera sustituir aquella pena, después de haberse cumplido diez años de condena, por la de deportación ${ }^{13}$. Era el juez o tribunal que había dictado la sentencia el competente para acordar esta sustitución ${ }^{14}$, pero tenía que solicitarla el reo ${ }^{15}$.

9 Citado por B. M. Bernal y GaIPO, «La pena de muerte en España», en C. GARCÍA Valdés (dir.), La historia de la prisión, teorías economicistas. Crítica, Madrid, Edisofer, 1997, p. 61. El citado benedictino se opuso a la pena capital tras comprobar que los delitos se multiplicaban a pesar de su imposición, lo cual demostraba que no sirve de escarmiento para otros.

${ }^{10}$ Véase M. Foucault, Vigilar y castigar, traducción al castellano de A. GaRzón DEL Camino, 9. ${ }^{a}$ ed., Madrid, Siglo XXI de España, 1994, p. 113.

${ }^{11}$ Pueden consultarse, por ejemplo, los arts. 39, 40, 42, 45, 46, 97 y 106.2.

${ }_{12}$ Como destacó Casabó Ruiz, a pesar de que la finalidad intimidatoria era la que predominaba, resulta difícil encontrar un texto punitivo donde la corrección del delincuente tuviese tanta relevancia. Véase J. R. CASABó RuIz, El Código Penal de 1822, tesis doctoral, Valencia, Facultad de Derecho de la Universidad de Valencia, 1968, pp. 360 y ss. Son diversos los preceptos del Código Penal de 1822 de los que se desprende dicha vocación correccional, como, por ejemplo, de los arts. 65, 100 y 144 a 148.

${ }_{13}$ Dicha posibilidad de sustituir una pena por otra está prevista en el art. 144 del Código Penal de 1822. Por otra parte, en relación a la pena de deportación, importa subrayar que en España nunca se aplicó como tal, sino simplemente como pena de destierro y expulsión del territorio, o al menos así lo aseguró Cuello Calón. Véase E. Cuello Calón, Penología, las penas y las medidas de seguridad. Su ejecución, Madrid, Reus, 1920, pp. 203, 204, 206 y 2013 a 215.

${ }_{14}$ Art. 146 del Código Penal de 1822.

15 Art. 147 del Código Penal de 1822. El reo tenía que hacer la súplica por escrito y entregarla al jefe del establecimiento en el que se encontraba para que él lo entregase al juez o tribunal. 
Por otra parte, también cabía la posibilidad de que al condenado a trabajos perpetuos se le concediese un indulto, posibilidad que tenía un especial interés por sus repercusiones políticas, pues esta figura suponía la intervención del poder ejecutivo en las decisiones del poder judicial, con lo cual, aunque indirectamente, aquél influía igualmente en las resoluciones del legislativo. Con esto se rompía con la idea liberal de la división estricta de poderes, lo cual explica que el indulto no fuese aceptado de buen grado, por mucho que en la Constitución Española de 1812 se le reconociese al monarca la facultad de indultar a los delincuentes ${ }^{16}$. Fue precisamente por esto por lo que los redactores del Código Penal tuvieron que recoger esta figura, pero para evitar arbitrariedades, abusos de poder e impunidad, optaron por una regulación minuciosa y detallada del mismo, recogiendo sus clases, casos en los que tenía lugar y formas ${ }^{17}$.

Conviene saber, asimismo, que en el Código también había una serie de supuestos que presentaban peculiaridades a la hora de aplicar la pena de trabajos perpetuos. Ésta no podía imponerse a los presbíteros, diáconos y subdiáconos, ni a las mujeres, ni tampoco a los septuagenarios. A los presbíteros, diáconos y subdiáconos, en lugar de imponérseles esta pena, se procedía a su deportación, lo cual se justificaba por honor al sacerdocio ${ }^{18}$. También las mujeres eran deportadas ${ }^{19}$, excepto si eran mayores de setenta años. A éstas, y también a los hombres septuagenarios, se les enviaba a una casa de reclusión ${ }^{20}$. Según Vicente y Caravantes, esta exclusión pretendía establecer cierta igualdad en la pena porque si se les aplicase con el

16 Art. 171 de la Constitución de 1812.

$17 \mathrm{Al}$ respecto véase J. R. CASABÓ Ruiz, El Código Penal de 1822, op. cit., pp. 387 y ss. En relación a los indultos y sus excepciones pueden consultarse los arts. 156 y ss. Importa apuntar que era el rey quien, haciendo uso de la facultad conferida por la Constitución, podía indultar de forma particular o general a los delincuentes. Los indultos particulares eran los que en alguna causa sobre un delito determinado se concedían al reo o reos comprendidos en ella, a no ser que el propio Código los excluyera de este beneficio, y siempre y cuando existiera sentencia condenatoria firme. No suponían ni un perdón absoluto ni una remisión de toda la pena, simplemente una disminución de la pena señalada por las leyes, conmutándola a voluntad del monarca por otra de las prescritas en el Código. Y los indultos generales eran los que se concedían sin determinación de causas ni personas a todos cuantos habían delinquido, y podían contener un perdón absoluto o remisión de toda pena. Los podía conceder el rey en las ocasiones faustas de su coronación, su boda o la del príncipe de Asturias, del nacimiento de algún infante o de la firma de algún tratado de paz, y era a favor de los individuos que todavía no estaban condenados, siempre y cuando no estuviesen excluidos de dicha posibilidad, pues existían excepciones a la concesión de las dos clases de indultos.

18 Art. 69 del Código Penal de 1822.

19 Art. 67 del Código Penal de 1822.

${ }^{20}$ Art. 66 del Código Penal de 1822. 
mismo rigor que al resto podría degenerar en la de muerte ${ }^{21}$. En parecido sentido se pronunció Pacheco, quien afirmaba que «tanto la vejez como la debilidad del sexo han de eximir de ciertas condenas durísimas». Explicaba este autor que a la hora de aplicar una pena a los dichos colectivos se seguían reglas de decencia y humanidad cuya concepción, según él, es tan natural y sencilla que en aquel entonces no había ni un solo Código que no las hubiese consagrado.

\section{El Código Penal de 1848}

La vigencia del Código Penal de 1822 fue efímera debido a la restauración del absolutismo de Fernando VII 22 . Se volvió a una etapa de represión y a la legislación medieval, y a pesar de que con el tiempo el monarca se mostró favorable al despotismo ilustrado y aceptó la necesidad de promulgar un nuevo Código, ninguno de los proyectos llegó a convertirse en Ley. Aquél tampoco vio la luz bajo la vigencia de la Constitución de 1837, de carácter liberal progresista. Cuando se aprobó finalmente dicho texto legal, en 1848, regía una Constitución moderada, la aprobada en 1845. En su elaboración jugó un papel protagonista Pacheco, el cual partía de la teoría de los fines de la pena de Rossi. Éste creó un sistema mixto, aunque con un claro predominio de la justicia sobre la utilidad. Daba un mayor protagonismo a la finalidad retributiva, basada en la idea de la retribución del mal por el mal y la expiación del delito. Además, para él la base es el orden moral prexistente en todas las cosas, eterno, inmutable. No creía en la división entre orden moral y orden jurídico. Por otra parte, también interesa saber que el Código Penal de 1848 fue reformado por Real Decreto de 30 de junio de 1850, pero los retoques fueron mínimos y no afectaron a la pena de cadena perpetua, sucesora de la de trabajos perpetuos.

La pena de trabajos perpetuos no estaba prevista en el Código Penal de 1848 pero esto no quiere decir que desapareciera, más bien cambió de nombre. Dicha pena se convirtió en la de cadena perpetua ${ }^{23}$, la cual, igual que aquélla, aparte de la privación de libertad llevaba aparejada la obliga-

\footnotetext{
${ }^{21}$ J. Vicente y Caravantes, Código Penal reformado comentado novísimamente, MadridSantiago, Librerías de Don Ángel Callejar, 1851, pp. 216-217.

${ }^{22}$ Ello supuso la abolición tanto de la Constitución como de los textos penales promulgados durante el periodo constitucional, pero no de los anteriores.

${ }^{23}$ Art. 6 de los Códigos Penales de 1848 y 1850.
} 
ción de quedar sujeto a una cadena y trabajar en beneficio del Estado en trabajos duros y penosos, aunque con una excepción: el tribunal, después de comprobar la edad, la salud, el estado o cualquier otra circunstancia del reo, podía indicar en la sentencia que aquél tenía que ocuparse de los trabajos inferiores del establecimiento ${ }^{24}$.

Tanto sufrimiento, según algunos autores, era necesario. Según Pacheco, no podía ser de otra manera, pues de no ser tan grave y terrible, la consecuencia sería la multiplicación de manera inconveniente de la pena capita ${ }^{25}$. De manera parecida también se pronunciaron Vizmanos y Álvarez Martínez, los cuales no defendieron de manera expresa los sufrimientos a los que eran sometidos los condenados a cadena perpetua, pero sí los toleraban, principalmente porque permitían sustituir la pena de muerte y reducir su aplicación, reservándola para los delitos más graves. La de cadena era una pena gravísima pero no presentaba los defectos de la pena capital, cuyo campo de aplicación continuaba limitándose ${ }^{26}$.

$\mathrm{Y}$ a los indicados todavía se sumaban otros sufrimientos, pues se ordenaba destinar a los condenados a lugares lo más lejanos posible de sus domicilios, lejos de la familia, en destinos con un clima y unos alimentos muy diferentes a los que estaban acostumbrados, y a los que llegarían después de un duro y largo trayecto ${ }^{27}$. Esta sanción debía cumplirse en cualquiera de los puntos destinados al efecto en África, Canarias o Ultramar, o al menos así estaba previsto en el Código Penal ${ }^{28}$. Sin embargo, no siempre existían en los destinos indicados establecimientos adecuados donde encerrar a los condenados, por ello que la Ley de Prisiones de 26 de julio de 1849 ordenaba enviar a los sentenciados a cadena a los presidios de la Península, de Baleares y de Canarias, hasta poder ser trasladados oportunamente a los respectivos destinos penales ${ }^{29}$. Años más tarde se decidió que los condenados a la pena que estamos analizando cumpliesen condena en el presidio de Ceuta, en las dependencias de Melilla, Alhucemas y el Peñón, o en los presidios existentes o que se construyesen en las islas adyacentes, tal y como figuraba en la Ley de Bases de 21 de octubre de 1869. Aquí también se introducía una excepción: cuan-

${ }^{24}$ Art. 96 de los Códigos Penales de 1848 y 1850.

${ }^{25}$ Véase J. F. PACheCo, El Código Penal concordado y comentado, vol. I, Madrid, Imprenta de la Viuda de Perinat y Compañía, 1856, pp. 322 y 462.

${ }^{26}$ Véase T. M. Vizmanos y C. Álvarez Martínez, Comentarios al Código Penal, vol. I, Madrid, Establecimiento Tipográfico de J. González y A. Vicente, 1848, pp. 347-348 y 351.

27 Ibid., p. 351.

28 Art. 94 de los Códigos Penales de 1848 y 1850.

29 Art. 23 de la Ley de Prisiones de 26 de julio de 1849. 
do la pena en cuestión sustituyese a la de muerte, la condena se cumpliría en los establecimientos creados al efecto con el nombre de colonias penitenciarias en las posesiones españolas en el Golfo de Guinea o de las Islas Filipinas ${ }^{30}$.

Debe tenerse en cuenta, asimismo, que la pena de cadena perpetua se imponía junto con otras accesorias ${ }^{31}$. Las penas de interdicción civil y de inhabilitación perpetua se imponían siempre, y en algunos casos también la de degradación civil y la de argolla. En concreto, la degradación civil se imponía si los condenados eran empleados prevaricadores o si habían abusado de su destino público, y la pena de argolla se aplicaba cuando el delito cometido era de traición, regicidio, parricidio, robo o muerte con alevosía, o si se había ejecutado por precio, recompensa o promesa, siempre y cuando lo hubiesen cometido diversas personas y a alguna de ellas se le hubiese impuesto la pena de muerte, excepto cuando esta pena hubiese recaído sobre el descendiente, ascendiente, cónyuge o hermano del sentenciado a muerte ${ }^{32}$.

Además, en principio la pena en cuestión debía cumplirse a pulso. No se contemplaba la posibilidad de sustituirla por otra, ni de duración temporal ni perpetua. Siendo así, y como apuntó Vicente y Caravantes, la pena en cuestión presentaba el grave inconveniente de desmoralizar al culpable, en lugar de corregirlo, de arrancarle toda esperanza de volver a la sociedad, y de destrozar el arrepentimiento y la rehabilitación moral ${ }^{33}$. Y como él opinaba Pacheco. No obstante haber asumido un papel protagonista en la elaboración del Código, Pacheco afirmó lo siguiente: «Toda pena perpetua tiene para nosotros alguna cosa de repugnante que difícilmente perdonamos por todas las consideraciones que la recomienden. Esa inflexibilidad es contraria a nuestras ideas morales en tanto a la expiación y el mérito del arrepentimiento» ${ }^{34}$.

${ }^{30}$ Allí irían a parar también los condenados a relegación perpetua y los penados incorregibles después de cumplir penas aflictivas durante veinte años.

31 Arts. 52 y 55 de los Códigos Penales de 1848 y 1850.

32 En general la doctrina veía correctas las penas accesorias indicadas, excepto la de argolla, rechazada por ser una pena infamante y porque, debido a que la pena de muerte no la llevaba implícita, imprimía a la de cadena perpetua una gravedad mayor que la que tenía aquella otra. Así lo criticaron, entre otros, los siguientes autores: T. M. Vizmanos y C. ÁLVARez Martínez, Comentarios al Código Penal, op. cit., vol. I, pp. 274-277; J. Vicente y CaravANTES, Código Penal reformado comentado novísimamente, op. cit., pp. 170, 172 y 275-276, y J. F. PACHeCo, El Código Penal concordado y comentado, op. cit., vol. I, pp. 345-346 y 366-367.

33 J. Vicente y J. Caravantes, Código Penal reformado comentado novísimamente, op. cit., p. 146.

${ }^{34}$ J. F. PACheco, El Código Penal concordado y comentado, op. cit., vol. I, p. 315. 
Ahora bien, el monarca continuaba pudiendo indultar a los condenados a perpetuidad, lo cual suavizaba las críticas. En palabras de Pacheco: «Una sola cosa absuelve y justifica para nosotros este género de penas, a saber: el derecho de indultar que se concede al soberano» ${ }^{35}$. Incluso quienes no creían en la corrección de los condenados a cadena perpetua reconocían que esta pena chocaba con las opiniones de quienes sí confiaban mucho en la misma y aplaudían que al menos se incluyese la opción del indulto. Éste sería el caso de Vizmanos y Álvarez Martínez, según los cuales el indulto es el mejor estímulo para el arrepentimiento ${ }^{36}$. Tal y como figuraba en el Código Penal de 1848, su concesión implicaba la no ejecución de la pena impuesta, pero de la principal, no de las accesorias, o al menos no de todas. Se advertía que el indulto no producía la rehabilitación para el ejercicio de los cargos públicos y derechos políticos, ni eximía de la sujeción a la vigilancia de la autoridad, excepto si así se indicaba expresamente ${ }^{37}$.

Y juntamente a lo dicho hasta ahora, también debe tenerse en cuenta que la pena de encierro de por vida seguía vetada a determinados colectivos: a las mujeres de cualquier edad y a los hombres mayores de sesenta años. Se continuaba creyendo que las mujeres eran el sexo débil y que, en el caso de los ancianos, el trabajo duro impuesto podía acortar su vida, degenerando para ellos la pena en un suplicio más bárbaro y cruel que la muerte, aparte de que, según apuntaron Vizmanos y Álvarez Martínez, la vejez inspiraba compasión y exigía que el castigo en este caso se suavizase, pues en los ancianos podían nacer todavía sentimientos buenos, ya que, amortecidas las pasiones, era de esperar que si no se producía la inclinación hacia el bien, se debilitara al menos la propensión al mal conforme disminuía el poder de dañar ${ }^{38}$. Hay que apuntar, asimismo, que la razón por la cual se pasó de los setenta años -fijada en el Código Penal español de 1822 y en otros Códigos europeos- a los sesenta era que se creía que la naturaleza de nuestro clima hace envejecer más pronto ${ }^{39}$. Sea como fuere, tanto las mujeres como los hombres mayores de esta edad que cometían un delito castigado con pena de cadena perpetua tenían que ser

35 Ibid.

36 T. M. Vizmanos y C. Álvarez Martínez, Comentarios al Código Penal, op. cit., vol. I, pp. $225-226$.

37 Art. 45 de los Códigos Penales de 1848 y 1850.

38 T. M. Vizmanos y C. Álvarez Martínez, Comentarios al Código Penal, op. cit., vol. I, pp. 352-353.

39 J. F. PACheCo, El Código Penal concordado y comentado, op. cit., vol. I, p. 466. 
enviados a una casa de presidio mayor ${ }^{40}$, aunque mientras se habilitaban o construían los establecimientos necesarios para ello, las mujeres cumplieron condena en los destinados exclusivamente al encierro de personas de su mismo sexo, procurando la separación de las condenadas a reclusión, presidio y prisión $^{41}$.

\section{El Código Penal de $\mathbf{1 8 7 0}$}

En 1868, tras la revolución conocida como «La Gloriosa» y la huida de la reina Isabel II a Francia, comenzó el llamado Sexenio Revolucionario, a lo largo del cual se promulgó la Constitución de 1869 y, en armonía con ésta, el Código Penal de 1870, el cual, además de ser en realidad una reforma del de 1848, fue planteado como una ley provisional aplicable a la Península e islas adyacentes, según el Decreto de 30 de agosto de 1870 del ministro de Hacienda, Gracia y Justicia, Laureano Figuerola, aunque luego estuvo en vigor cincuenta y ocho años. Ni la promulgación en 1876 de la nueva Constitución, que además obligaba a acomodar el Código a sus preceptos, ni los progresos en el Derecho internacional y en la legislación de los países de nuestro entorno, ni tampoco los avances de la ciencia y la práctica penitenciarias, propiciaron la aprobación de un Código Penal nuevo, y ello a pesar de la insistencia de la doctrina en la necesidad de hacerlo. El propio Groizard, uno de los artífices de aquél, insistía en la necesidad de reformarlo para añadir nuevos prestigios a los ya adquiridos durante todo el tiempo que había sido baluarte del orden público y garantía suficiente de los derechos sociales y particulares más apreciados ${ }^{42}$.

En este Código, que como hemos apuntado era una reforma del de 1848, predominaba la finalidad retributiva de la pena ${ }^{43}$. Tanto es así que Jiménez de Asúa y Antón Oneca llegaron a afirmar que respondía por

\footnotetext{
40 Arts. 98 y 99 de los Códigos Penales de 1848 y 1850.

${ }^{41}$ Disposición transitoria primera del Código Penal de 1848 y disposición transitoria segunda del Código Penal de 1850.

42 A Groizard y Gómez de la Serna, El Código Penal de 1870 concordado y comentado, vol. I, 2. ${ }^{a}$ ed. corregida y aumentada, Madrid, Establecimiento tipográfico de los Hijos de J. A. García, 1902, p. 10. Este penalista creía que la aprobación de un nuevo texto legal podía hacerse conservando las bases esenciales del entonces vigente y sin alterar su estructura.

${ }^{43}$ Ejemplo de ello son el art. 26 del Código Penal de 1870 en relación con el 27, o el art. 129 , reglas primera y segunda.
} 
completo a la retribución ${ }^{44}$. No obstante, la prevención general también estaba presente ${ }^{45}$ y tenía cabida, asimismo, la prevención especial, entendida como aspiración correccional o reformadora ${ }^{46}$. Téngase en cuenta que por aquella época llegaron a España, directamente desde Alemania, las ideas de la Escuela Correccionalista, las cuales calaron, aunque con distinta intensidad, entre penalistas de prestigio, como Luis Silvela, Concepción Arenal, Dorado Montero y Jiménez de Asúa. Y aunque estos últimos opinaban que tal finalidad estaba presente de manera más simbólica o formal que real ${ }^{47}$, lo cierto es que contribuyó a que, a pesar de la inclusión en el catálogo de penas de dos de duración perpetua, la de cadena y la de reclusión a perpetuidad, se introdujese la obligatoriedad de indultar a los condenados pasados treinta años, con la condición de que no habitasen en el lugar de residencia del ofendido por el delito cometido, a no ser que éste diese su consentimiento para que pudiesen hacerlo. Si lo incumplían, el indulto quedaba sin efecto ${ }^{48}$.

Ahora bien, se preveía una excepción al indulto: que los condenados, por su conducta o por otras circunstancias graves, no fuesen dignos del mismo, a juicio del gobierno ${ }^{49}$. En estos casos tampoco servía de nada que además del indulto en el Código también estuviera prevista la posibilidad de conceder una amnistía $a^{50}$, la cual, en palabras de Langle, significaba la abolición u olvido, pues a diferencia del indulto, que solamente borraba lo futuro, la amnistía también borraba lo pasado, es decir, toda la memoria del delito cometido, también los antecedentes penales, o, en otras palabras, extinguía por completo la pena y todos sus efectos ${ }^{51}$.

Aparte de lo dicho, otras cosas que conviene saber de la pena de cadena perpetua es que tenía que cumplirse en África, Canarias o Ultramar ${ }^{52}$, aunque con el tiempo los sentenciados a ésta y otras penas fueron trasladados a la Península. El año 1898 concluyó con la emancipación de Cuba,

${ }^{44}$ L. Jiménez de Asua y J. Antón Oneca, Derecho penal conforme al Código Penal de 1928, Madrid, Reus, 1929, p. 482.

${ }^{45}$ Valen de ejemplo los arts. 26, 102 y ss. del Código Penal de 1870.

46 Valen de ejemplo los arts. 25; 26; 115, último párrafo, y 116, tercer párrafo, del Código Penal de 1870.

${ }^{47}$ L. Jiménez de Asua y J. Antón Oneca, Derecho penal conforme al Código Penal de 1928, op. cit., pp. 482-483.

48 Art. 132.4 del Código Penal de 1870.

49 Art. 29 del Código Penal de 1870.

50 Art. 132.3 del Código Penal de 1870.

51 E. Langle Rubio, Código Penal de 17 de junio de 1870, Madrid, Hijos de Reus Editores, 1915 , p. 210.

52 Art. 106 del Código Penal de 1870. 
Puerto Rico y Filipinas del dominio español, con lo cual allí ya no se podía enviar a sentenciados a cumplir sus respectivas condenas, y, por otra parte, la Ley de Presupuestos Generales del Estado de fecha 1 de enero de 1907 consignó la suma necesaria para trasladar a la Península a los reos que estuviesen en los presidios de África ${ }^{53}$.

En cualquier caso, con independencia del lugar de cumplimiento, y como venía sucediendo, los condenados quedaban obligados a trabajar en beneficio del Estado en trabajos duros y penosos, dentro o fuera del establecimiento penitenciario, pero siempre atados a una cadena ${ }^{54}$, aparte de que se les imponían otras penas accesorias, a saber: la degradación, en caso de que aquélla se impusiese a un empleado público por abuso cometido en el ejercicio de un cargo de carácter permanente, y, siempre, la interdicción civil, que era perpetua y absoluta, incluso cuando el condenado obtenía el indulto de la pena principal, a no ser que en aquél se indicase lo contrario de manera expresa ${ }^{55}$.

Las mujeres continuaban sin poder cumplir la pena de cadena perpetua, aunque sí podían cumplir la de reclusión de por vida. De hecho, en caso de haber cometido un delito que llevase aparejada aquella pena se les hacía cumplir esta otra ${ }^{56}$. Tampoco se consideraba la de cadena perpetua una pena adecuada para personas mayores de sesenta años y en lugar de ésta cumplían la de presidio mayor, donde permanecían hasta el fin de sus días ${ }^{57}$.

Y en relación a la pena de reclusión perpetua, además de que se consideraba apta para personas de ambos sexos y de todas las edades, cabe decir que podía cumplirse dentro o fuera de la Península, en establecimientos adecuados, en el interior de los cuales los reos se ocupaban en trabajos en beneficio del Estado ${ }^{58}$, y además de la privación de libertad y de la obligación de trabajar que su imposición implicaba, los sentenciados también tenían que cumplir la pena accesoria de inhabilitación perpetua absoluta, con la cual sucedía lo mismo que cuando acompañaba a la pena de cadena perpetua, pues el indulto no ponía fin a la misma, a no ser que se indicase en éste lo contrario de manera expresa ${ }^{59}$.

53 E. Langle Rubio, Código Penal de 17 de junio de 1870, op. cit., p. 189.

54 Arts. 107 y 108 del Código Penal de 1870.

55 Art. 54 del Código Penal de 1870.

${ }^{56}$ Art. 96 del Código Penal de 1870.

57 Art. 109 del Código Penal de 1870.

58 Art. 110 del Código Penal de 1870.

59 Art. 55 del Código Penal de 1870. 


\section{LAS PENAS DE ENCIERRO PERPETUO EN LOS CÓDIGOS DEL SIGLO XX}

\section{El Código Penal de $\mathbf{1 9 2 8}$}

A comienzos del siglo xx se celebraron en España una serie de congresos internacionales en los que se planteó la necesidad de aprobar un Código Penal adaptado a los nuevos tiempos ${ }^{60}$. De estos congresos el más importante fue el celebrado en la Coruña en 1914, en el cual, entre otras cosas, se propuso la supresión de las penas infamantes de la escala contemplada en el Código de 1870 (entre las cuales estaba la de cadena perpetua), así como la creación de la figura de la libertad condicional para el último periodo de la condena ${ }^{61}$. Sin embargo, la deseada reforma no llegaba, y en esta espera influyó el que el reinado de Alfonso XII estuvo marcado desde sus inicios por la inestabilidad social. Esta situación en 1923 era caótica y ello sirvió al general Primo de Rivera para hacerse cargo del poder mediante manifiesto de 13 de septiembre de dicho año. Comenzó entonces una etapa dictatorial que duró hasta 1929. Hay que saber que el nuevo régimen en un principio no derogó el Código Penal de 1870, sino que se limitó a promulgar diversas leyes penales, tanto especiales como complementarias, dirigidas a su inmediata adecuación a la concepción política autoritaria del Estado o a la modificación de algún precepto de aquél. La reforma definitiva tuvo lugar con la promulgación del Código Penal de 1928.

A decir verdad, en 1926 se puso en marcha la tarea codificadora. El Real Decreto de 12 de marzo de 1926 dirigió a la Sección Penal de la Comisión Codificadora una serie de bases a partir de las cuales se tenía que reformar el Código Penal. No se pretendía elaborar un texto nuevo, sino una edición renovada del de 1870. De hecho, el propio ministro de Gracia y Justicia opinaba que no se debe legislar en caliente, o, como él dijo: «La confección de una ley penal es la obra legislativa que, además de competencia, requiere mayor serenidad de espíritu y más rectitud al pensar» ${ }^{62}$.

${ }^{60}$ Nos referimos a los congresos penitenciarios celebrados en Valencia el primero, en 1909; en la Coruña el segundo, en 1914, y en Barcelona el tercero, en 1920.

${ }^{61}$ C. Herrero Herrero, España penal y penitenciaria (historia y actualidad), Madrid, Dirección General de la Policía, División de Formación y Perfeccionamiento, Instituto de Estudios de la Policía, 1985, pp. 296-297, recogiendo las principales conclusiones a las que se llegó en el Segundo Congreso Penitenciario Español celebrado en la Coruña en 1914.

${ }_{62}$ L. San Martín Losada, El Código Penal de 1928, su estudio y comparación con el de 1870, prólogo de Ramón GarCía del VALLE, Madrid, Imprenta Clásica Española, 1928, p. 23. 
No obstante, la Comisión de Códigos fue más allá y el Código Penal que se aprobó en 1928 era distinto al de 1870, con orientaciones nuevas y con innovaciones tan extraordinarias que no puede considerarse de modo alguno una revisión del anterior ${ }^{63}$. Aquella Comisión de Códigos redactó un proyecto que, revisado por la Comisión Permanente, fue elevado al Ministerio el 12 de julio de 1927 y sometido después a informe de la Asamblea Nacional, que despachó un proyecto de tanta importancia. Volvió al Ministerio y, poco después de una revisión realizada por el ministro, por Real Decreto de 8 de septiembre de 1928 quedó aprobado.

El ministro de Justicia y Culto recibió un aplauso fervoroso por las correcciones introducidas, porque dulcificaba las sanciones que aquél contenía, pues, a pesar de no renunciar a la pena de muerte, al menos sí daba satisfacción a la propuesta de supresión de las penas privativas de libertad de duración perpetua ${ }^{64}$. Sin embargo, al acabar de cumplirse una pena de esta naturaleza podía empezar el cumplimiento de una medida de seguridad de la misma naturaleza ${ }^{65}$.

Efectivamente, en este Código Penal de 1928 se instauraron por primera vez en la legislación penal española las medidas de seguridad posdelictuales a imponer a sujetos enteramente imputables, de ambos sexos y de cualquier edad, y entre ellas encontramos la de encierro en un establecimiento especial ${ }^{66}$ de individuos que tuviesen la consideración de delincuentes habituales o incorregibles, cuya duración estaba totalmente indeterminada, con lo cual podía durar hasta el momento de su muerte ${ }^{67}$. Se

${ }^{63}$ Ibid., p. 24; también en ÍD., Algunas observaciones sobre el nuevo Código Penal, Madrid, Publicaciones de la Real Academia de Jurisprudencia y Legislación-Reus, 1929, p. 9.

${ }^{64}$ San Martín Losada exclamaba: «Si aun así resulta represivo, figuraros qué sería el Proyecte de la Comisión de Códigos». Véase L. SAn Martín Losada, Algunas observaciones sobre el nuevo Código Penal, p. 10.

${ }^{65}$ Las medidas de seguridad podían ser privativas o no privativas de libertad, y estaban reguladas en los arts. 90 a 94, 96 y 99 a 107 del Código Penal de 1928.

${ }^{66}$ En principio esta medida debía cumplirse en un establecimiento especial para que tales sujetos estuviesen separados del resto de delincuentes, pero, como lamentaba San Martín Losada, dichos establecimientos todavía no estaban en funcionamiento. Véase L. San Martín Losada, El Código Penal de 1928, su estudio y comparación con el de 1870, $o p$. cit., p. 24. Este autor se quejaba de que de nada servían las medidas de seguridad si su aplicación se hacía imposible, aunque en realidad lo único imposible era su cumplimiento en lugares específicos.

${ }^{67}$ La habitualidad no ha de confundirse con la reiteración y la reincidencia. Se trata de una circunstancia que fue introducida como novedad en el Código Penal de 1929. Se entendía que cuando el culpable había estado condenado anteriormente dos o más veces por delitos graves, o cinco o más por delitos menos graves, recogidos en el mismo título, el tribunal podía apreciar la circunstancia extraordinaria de multirreinicidencia, y en dichos 
decidió proceder de esta manera por entender que el estado especial de predisposición de estos individuos, del cual resultaba la probabilidad de delinquir, constituía un peligro social.

Lo anterior pone en evidencia que la supresión de la perpetuidad, al menos en algunos casos, era únicamente aparente. A pesar de que se le daba importancia a la finalidad resocializadora de la pena, de ahí ${ }^{68}$, y por respeto a la dignidad humana, que se renunciara a las penas de encierro de por vida ${ }^{69}$, también estaba muy presente en el nuevo Código Penal la finalidad inocuizadora, como demuestra la introducción de la medida de seguridad indicada ${ }^{70}$. En cualquier caso, además de que también estaba presente la prevención general, la finalidad más arraigada respondía al sentido de expiación y retribución ${ }^{71}$.

Importa apuntar, por otra parte, que la supresión —aunque aparente- de las penas de encierro a perpetuidad implicó una ampliación de la extensión de las temporales, pero afortunadamente esta agravación se compensaba con la incorporación de la figura de la libertad condicional $^{72}$, muy bien considerada por los penalistas de aquel entonces, como Jiménez de Asúa, Antón Oneca, Cuello Calón y Groizard Gómez de la Serna $^{73}$, entre otros, por estimular el arrepentimiento y la enmienda de

casos el sujeto era declarado delincuente habitual si la naturaleza y modalidades de los delitos cometidos, los motivos determinantes, las condiciones personales o el género de vida llevado a cabo anteriormente, demostraban en él una tendencia persistente al delito, a juicio del tribunal.

${ }^{68}$ Jaramillo celebró la desaparición de las penas de encierro a perpetuidad por su incompatibilidad con la finalidad resocializadora o correccional de la pena. Según este autor, dichas penas desesperaban al reo en su mazmorra y no estimulaban al arrepentimiento. Sin embargo, debe tenerse en cuenta que los correccionalistas discreparon con ello, pues éstos afirmaban que el delito no es una mera perturbación antijurídica de la voluntad, sino una acción externa, aunque moral, perturbadora del orden jurídico, que no se limpiaba con el arrepentimiento, sino con una pena de naturaleza psíquica y física igual. Véase A. JARAMILLO GarCía, Novísimo Código Penal comentado y cotejado con el de 1870, vol. I, libro I, Salamanca, Imprenta de Silvestre Ferreira, 1928, pp. 276-277.

${ }_{69}$ La presencia de la finalidad referida se pone de manifiesto, por ejemplo, en los arts. 104 y 105 del Código Penal de 1928.

${ }^{70}$ Existen otros muchos ejemplos. Pueden consultarse los arts. 90 a 107 y 157, y muy especialmente los arts. 103 y 157 del Código Penal de 1928.

${ }^{71}$ Valen de ejemplo los arts. 87 a 89, 108 a 123 y 163 a 183 del Código Penal de 1928.

72 En realidad se permitió que los condenados cumplieran la última parte de la condena en libertad condicional antes de la aprobación y entrada en vigor del Código Penal de 1928. A pesar de que el Código Penal de 1870 obligaba al cumplimiento íntegro de la pena en el interior de un establecimiento penitenciario, por Real Decreto de 23 de julio de 1914 se aprobó la Ley de Libertad Condicional y por Decreto de 28 de octubre de 1914 su Reglamento.

73 Alejandro Groizard colaboró en la comisión legislativa que, bajo la dirección de Nicolás María Rivero, redactó el Código Penal de 1870. 
los culpables con la esperanza de librarse del cumplimiento de una parte de la pena ${ }^{74}$.

\section{El Código Penal de 1932}

Después de la dimisión forzada de Primo de Rivera en 1929, el general Berenguer asumió el poder, pero la situación era insostenible y el régimen por él liderado, conocido como la Dictablanda, acabó cuando las elecciones municipales de 1931 dieron la victoria a la coalición de izquierdas en la mayoría de las capitales de provincia. El monarca abandonó el país y el 14 de abril de 1931 Alcalá Zamora, presidente del gobierno provisional, declaró constituida la Segunda República española.

Y proclamada la Segunda República, además de aprobarse una nueva Constitución, se derogó el Código Penal de 1928. Provisionalmente se volvió al Código de 1870, que, recordemos, no era sino una reforma del aprobado en 1848, y a partir de éstos ${ }^{75}$, y partiendo del mismo sentido expiatorio y retributivo que predominaba en ellos ${ }^{76}$, se elaboró el de 1932. El objetivo era la aprobación, en cuanto fuese posible, de un texto legal genuino, pero esto requería tiempo. Como se advertía en la Exposición de

${ }^{74}$ Los requisitos para poder beneficiarse de aquélla irán cambiando con el tiempo, pero no está de más dejar constancia de cuáles eran en el Código de 1928: haber pasado por los demás periodos del sistema penitenciario progresivo, haber extinguido las partes alícuotas de la condena establecidas en los reglamentos y ser merecedor de ella por haber dado pruebas evidentes de conducta ejemplar, y ofrecer garantías de hacer vida en libertad como ciudadano pacífico y laborioso. Se advertía, igualmente, que el requisito temporal, la exigencia de haber cumplido determinada parte de la condena, podía ser más flexible si los reos no se limitaban al cumplimiento de sus deberes y a la observación de la disciplina, sino que se distinguían por actos extraordinarios que mostraban su arrepentimiento y propósitos firmes de ser buenos ciudadanos, como realizar trabajos de mérito notorio, ayudar a la Administración o a los funcionarios del establecimiento en momentos peligrosos, o realizar actos de abnegación y sacrificio. En estos casos podía avanzarse la concesión de la libertad condicional. Véanse arts. 171 y 174 del Código Penal de 1928.

75 Puede afirmarse que el Código Penal de 1932 era una edición nueva del Código Penal de 1848, como también lo fue el de 1870. Véanse E. Cuello Calón, Derecho Penal. Parte General, 3. ${ }^{a}$ ed. considerablemente aumentada y adaptada al Código Penal de 1932, Barcelona, Bosch, 1935, p. 149, y M. Barbero Santos, Política y Derecho penal en España,

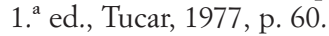

${ }^{76}$ A pesar de que la prevención general y la especial también estaban presentes y que ésta incluso llegaba a alcanzar un mayor protagonismo, este Código tenía el mismo sentido expiatorio y retributivo que el de 1870, por mucho que, como apuntó Cuello Calón, se intentara atenuar su exteriorización. Véase E. Cuello Calón, Derecho Penal. Parte General, op. cit., pp. 547-548. 
Motivos del Código Penal de 1932, todas las épocas revolucionarias precisan acelerar las tareas legislativas, pero no pueden atropellar las etapas de los trabajos que tienen largos periodos de gestación. En pocos meses era imposible preparar un proyecto de Código Penal completamente nuevo, pero también resultaba imposible mantener intacto el de 1870, de ahí que se optara por una solución intermedia: reformar este Código y dejar para más adelante la creación de uno nuevo ${ }^{77}$.

Las reformas incorporadas al texto punitivo de 1870 eran de diferentes clases, pero aquí únicamente interesa subrayar que, igual que la de muerte, la cadena y la reclusión perpetuas desaparecieron del cuadro de penas. La pena más grave era la de reclusión mayor, reservada a los hombres y que podría llegar a durar treinta años, pero ya no se admitían excepciones a la excarcelación de los condenados después de cumplir ese plazo $^{78}$ y dicha excarcelación ya no era una concesión, no se requería de un indulto ordenándola. A las mujeres no se les imponía esa sanción, pero también podían estar encerradas cumpliendo una pena privativa de libertad hasta un máximo de treinta años.

Decir cabe, asimismo, que extramuros del Código Penal, en la Ley de Vagos y Maleantes de 1933 se preveía la imposición de una medida de seguridad privativa de libertad a determinados sujetos imputables y su cumplimiento inmediatamente después de cumplida la pena de la misma naturaleza que hubiese resultado impuesta, pero dicha medida tenía una duración que, aunque indeterminada, no podría exceder de los cinco años.

En principio no puede decirse que pasara como cuando estaba vigente el Código Penal de 1928, esto es, que la desaparición de las sanciones perpetuas fuese únicamente aparente, aunque bien mirado sí lo era, pues sumando el tiempo de cumplimiento de la pena y el de la medida, un sujeto podía estar treinta y cinco años privado de libertad, periodo más que extenso que, dependiendo de la edad que tuviera el reo al inicio de la ejecución de la condena, podía abarcar toda su vida.

En relación a las medidas de seguridad justo es decir, además de lo anterior, que en la Ley de Vagos y Maleantes de 1933 se contemplaban medidas para determinados estados peligrosos, tanto predelictuales como posdelictuales, aunque aquí únicamente interesan las segundas, y no todas, sólo las de encierro en un establecimiento de custodia. Para su imposición

\footnotetext{
77 Exposición de Motivos del Código Penal de 1932, p. 6.

${ }^{78} \mathrm{La}$ pena de reclusión mayor era la más grave y tenía una duración máxima de treinta años.
} 
ni siquiera se requería que fuesen delincuentes habituales o incorregibles. Dicha medida podía imponerse a los delincuentes reincidentes o reiterantes de toda clase de delitos en los que fuese presumible la habitualidad criminal, y también a los sujetos criminalmente responsables de un delito cuando el tribunal sentenciador hiciese declaración expresa sobre su peligrosidad. Decir cabe, igualmente, que en caso de declararse el estado peligroso de un sujeto, la condena impuesta se cumplía íntegramente, pues dicho individuo no podía beneficiarse de la libertad condicional ${ }^{79}$.

\section{El Código Penal de 1944}

La Segunda República fue un sistema conveniente a una burguesía de clase media liberal y de menestrales, y encontró oposición por parte de la clase obrera, los comunistas y libertarios, por un extremo, y por parte de los grandes latifundistas y los sectores más reaccionarios de la sociedad, por el otro. El resultado fue el inconformismo y críticas de los primeros y el alzamiento militar de los segundos en julio de 1936, tras el cual dio inicio la Guerra Civil española, que terminó en 1939 con la victoria de los golpistas.

El estallido de la Guerra Civil precipitó el surgimiento de un impulso codificador que afectaba al Código Penal. Se pretendía adaptarlo a los principios esenciales de los alzados en armas contra la República ${ }^{80}$. Sin embargo, a pesar de que durante la contienda bélica se promulgaron normas represivas y de gran dureza en la zona franquista, a las cuales se añadieron otras disposiciones de tipo excepcional finalizada aquélla, hasta 1944 no se aprobó un nuevo Código Penal. Se declaró entonces derogado el de $1932^{81}$, aunque importa subrayar que el nuevo fue redactado de acuerdo con la Ley de 19 de julio de 1944, que tenía el objetivo de introducir modificaciones escasas en aquél, a la espera de su reforma total.

79 Arts. 3 a 7 de la Ley de Vagos y Maleantes.

${ }^{80}$ Se sucedieron diversos proyectos, aunque posiblemente el de mayor interés fuese el presentado en 1938 por la Delegación Nacional de Justicia y Derecho de Falange Española Tradicionalista y de las JONS. En su redacción participaron Luna García y Castejón, y Casabó Ruiz lo consideró uno de los proyectos con mayor interés de los formulados en aquella época. Fue un intento revolucionario y original en lo referente a la parte general, por tratar de romper con los principios liberales. Otro proyecto interesante fue el de 1939, que no era otra cosa que una reforma del Código Penal de 1932 aunque inspirada en el Código de 1928. Véase J. R. CAsabó Ruiz, «Estudio Preliminar», en El Anteproyecto de Código Penal de 1938 de FET y de las JONS, Murcia, Departamento de Derecho Penal y Secretariado de Publicaciones de la Universidad de Murcia, 1978, p. 4.

${ }^{81}$ Disposición final y art. 604 del Proyecto de Código Penal de 1939. 
Siendo así, el Código Penal de 1944 no es más que una edición renovada o actualizada del viejo cuerpo de leyes penales, que en su sistema fundamental y en muchas de sus definiciones y reglas databa del promulgado en $1848^{82}$, y como en éste los fines de la pena a los que se les atribuía mayor importancia eran los de expiación y retribución, seguidos del de intimidación ${ }^{83}$, aunque, como en sus antecesores, también podemos encontrar algún indicio de prevención especial de carácter constructivo o correccional ${ }^{84}$. Al franquismo le interesaba convertir a sus opositores en patriotas fieles a los principios y valores del nuevo régimen, pero se creía que dicha corrección no siempre era posible.

En relación a esto último, el propio Franco dejó muy claro que para él y para el régimen no se tenía que proceder del mismo modo con todos los condenados, pues partían de la base de que no todos los reos eran iguales: «Hay en el caso presente de España dos tipos de delincuentes: los que llamaríamos criminales empedernidos, sin posible redención dentro del orden humano, y los capaces de sincero arrepentimiento, los redimibles, los adaptables a la vida social del patriotismo» ${ }^{85}$.

A los primeros, ya fuesen hombres o mujeres, ya fuesen jóvenes o ancianos, les esperaba la muerte — pena que restableció el Código Penal franquista- o el encierro inocuizador durante un máximo de treinta años o, en caso de concurrencia de delitos diferentes, durante cuarenta $^{86}$. Se amplió, pues, el límite máximo de tiempo que una persona podía estar privada de libertad, y a esos años todavía cabía sumar los cinco que podía durar la medida de seguridad de encierro en un establecimiento de custodia prevista en la Ley de Vagos y Maleantes, la cual continuó en vigor durante el franquismo ${ }^{87}$. Como se sabe, esta medida podía imponerse a los sujetos de ambos sexos y de cualquier edad que resulta-

82 Preámbulo del Código Penal de 1944, p. 5.

${ }^{83}$ En relación a la importancia que se le daba a la prevención general negativa, esto es, a la intimidación de la población en general, además de figurar en el Preámbulo del Código Penal de 1944, en la p. 9, se desprende de los arts. 27 a 48.

${ }_{84}$ Pueden consultarse, por ejemplo, los arts. 27 y 65 del Código Penal de 1944.

85 F. Franco, El Diario Vasco, 1 de enero de 1939.

${ }^{86}$ Después de la de muerte la pena más grave era la de reclusión mayor, con la duración arriba indicada. Al respecto pueden consultarse los arts. 27 y 75.1. ${ }^{a}$ del Código Penal de 1944. Para más información sobre las penas de encierro durante la Guerra Civil, el franquismo y la transición véase T. GonzÁLEZ Collantes, «Las prisiones en el contexto de la Guerra Civil española, el franquismo y la transición a la democracia», E-Legal History Review, núm. 19 (2015), p. 35.

${ }^{87}$ La Ley de Vagos y Maleantes continuó en vigor, aunque fue modificada por el régimen franquista para incluir la represión a los homosexuales el 15 de julio de 1954. 
ban criminalmente responsables de un delito cuando el tribunal sentenciador hiciese declaración expresa sobre su peligrosidad, así como a los delincuentes reincidentes o reiterantes de toda clase de delitos en los que fuese presumible la habitualidad criminal. Y estos sujetos, además de que, como también se sabe, estaban excluidos del beneficio de la libertad condicional, con lo cual la pena primero y la medida después se cumplían íntegramente ${ }^{88}$, también lo estaban de la redención de pena por trabajo ${ }^{89}$. Con más razón incluso que cuando estaba vigente el Código Penal de 1932, cabe decir que la desaparición de la pena de cadena perpetua era únicamente teórica o aparente. Debe tenerse en cuenta que en el momento de aprobarse el Código Penal la esperanza de vida en España rondaba los sesenta años ${ }^{90}$.

El Código Penal franquista fue reformado en diversas ocasiones, en 1963, en 1967, por Ley de 1971 —que se convirtió dos años después en texto refundido del Código Penal—, en 1974, en 1976 y en 1977, pero ninguna modificación afectaba a las penas privativas de libertad. También se sucedieron diferentes proyectos, pero hasta el año 1995 no se aprobó un Código Penal nuevo.

Por otra parte, la Ley 16/1970, de 4 de agosto, sobre peligrosidad y rehabilitación social, sustituyó, o más bien reformó, la de Vagos y Maleantes de 1933, a tenor de la cual para imponer una medida de seguridad posdelictual se requería haber sido condenado por tres o más delitos y que fuese presumible su habitualidad criminal, previa declaración expresa de su peligrosidad social. Además, la medida privativa de libertad a imponer en estos casos reducía su duración máxima a tres años ${ }^{91}$. Esta Ley fue derogada completamente el 23 de noviembre de 1995.

${ }^{88}$ Arts. 3 a 7 de la Ley de Vagos y Maleantes.

89 Así consta en el art. 100 del Código Penal de 1944. Debe saberse, por otra parte, que a la redención de pena por trabajo se recurrió por primera vez durante la Guerra Civil, en 1937, aunque los antecedentes de la misma hay que buscarlos en el Derecho de justicia militar, en el que se incluyó para suavizar las penas privativas de libertad largas impuestas a los condenados por rebelión militar.

${ }_{90}$ Véase A. Carreras, Estadísticas históricas de España: siglos XIX-XX, Madrid, Fundación Banco Exterior, 1989. social.

${ }_{91}$ Arts. 4 a 7 de la Ley 16/1970, de 4 de agosto, sobre peligrosidad y rehabilitación 


\section{LAS PENAS DE ENCIERRO PERPETUO EN EL CÓDIGO PENAL DE 1995}

\section{La inclusión de manera encubierta de la pena de prisión perpetua}

Tras la muerte de Franco, y sobre todo después de la promulgación de la Constitución de 1978, la aprobación de un nuevo Código Penal constituía una necesidad histórica. Se pretendía que éste atendiese a una serie de principios doctrinales elaborados por el Senado, contenidos en un dictamen de fecha de 24 de mayo de 1978 que fue aprobado por 142 votos a favor y 9 abstenciones $^{92}$. En concreto, en dicho dictamen se requería atenuar la dureza de determinadas penas, profundizar en las investigaciones para superar la idea de que la cárcel es la única respuesta a la infracción penal, valorar la privación de libertad como una medida que causa daños graves a las personas, buscar alternativas a la pena de prisión y ampliar los supuestos de condena condicional. Debe saberse que por aquel entonces se publicaron diversos estudios que ponían en evidencia que la pena de encierro en un establecimiento penitenciario con una duración superior a los quince años tiene consecuencias negativas y graves en quienes la sufren, lo cual la puede convertir en una pena incompatible con la finalidad resocializadora, a la cual se le concedía mucha importancia, tanta que a ella se hace mención de manera expresa en el art. 25.2 de la Constitución, a tenor del cual las penas privativas de libertad y las medidas de seguridad tienen que orientarse a la reeducación y la reinserción social.

El nuevo Código Penal no se aprobó hasta 1995, y aunque pretendió avanzar en la dirección marcada durante los primeros años de la transición, en ese momento la resocialización no atravesaba por su mejor momento ${ }^{93}$. Prueba de ello es que el límite máximo de la pena de cárcel no se fijó en quince, sino en veinte años ${ }^{94}$, y había no pocas excepciones a

\footnotetext{
${ }^{2}$ Para conocer el contenido íntegro del Dictamen de 24 de mayo de 1978 véase LuRRA, Rebelión en las cárceles, Donostia-San Sebastián, Hordago, 1978, pp. 57 y ss.

${ }_{93}$ En relación a la evolución de la finalidad resocializadora de la pena véase T. GonZÁLEZ COLLANTES, «Auge y crisis de la resocialización. Crisis y auge de la pena de prisión», Cuadernos de Política Criminal, núm. 115, época II (2015), p. 39.

${ }^{94}$ Criticaron que dicho límite máximo resulta excesivo, entre otros, M. CoBo del Rosal y T. S. Vives Antón, Derecho Penal. Parte General, 5. ${ }^{a}$ ed. actualizada por M. L. Cuerda ARnau y M. Quintanar, Valencia, Tirant lo Blanch, 1999, p. 831; S. Mir Puig, Derecho Penal. Parte General, 9. a ed., Barcelona, Reppertor, 2011, p. 698, y B. Mapelli Caffarena y J. TerRadiLlos Basoco, Las consecuencias jurídicas del delito, 3. . ed., Madrid, Civitas, 1996, pp. 69 y ss. Y en relación a las críticas a las penas privativas de libertad demasiado largas véanse también
} 
esta regla general, pudiendo llegarse hasta los treinta años de encierro ${ }^{95}$, además de que en el art. 78 se preveía que en caso de concurso de delitos, cuando como consecuencia de las limitaciones establecidas en el art. 76 la pena a cumplir resultara inferior a la mitad de la suma total de las impuestas, el tribunal sentenciador, en atención a la peligrosidad criminal del sujeto, pudiera acordar motivadamente que los beneficios penitenciarios y el cómputo del tiempo para acceder a la libertad condicional se refiriesen a la totalidad de las penas impuestas en las sentencias. Se permitía que el juez de vigilancia penitenciara acordara la aplicación del régimen general de cumplimiento - para lo cual se debían valorar las circunstancias personales del reo, la evolución del tratamiento reeducador y el pronóstico de reinserción social, y escuchar a la Fiscalía-, con lo cual es posible que intentaran superarse las críticas de inconstitucionalidad formuladas contra ese régimen excepcional, pero aun así hay una parte de la doctrina que pone en duda la constitucionalidad del referido precepto, como es el caso de Muñagorri Laguía ${ }^{96}$, Mapelli Caffarena y Terradillos Basoco ${ }^{97}$, o López Garrido y García Arán ${ }^{98}$, por ejemplo ${ }^{99}$.

M. Barbero SANToS, «La pena de muerte, problema actual», en Estudios de Criminología y Derecho Penal, Valladolid, Universidad de Valladolid, 1972, p. 169; J. M. ${ }^{a}$ RodríGuEz DevesA y A. Serrano Gómez, Derecho Penal español. Parte General, 18. a ed., Madrid, Dykinson, 1995, pp. 905-906; I. Serrano Butragueño, Código Penal de 1995. Comentarios y jurisprudencia, Granada, Comares, 1999, p. 497; B. Mapelli Caffarena y J. TerRadillos Basoco, Las consecuencias jurídicas del delito, op. cit., pp. 69-71; G. Quintero Olivares, Parte general del Derecho penal, 4. a ed., Madrid, Aranzadi, 2010, p. 710, y E. Orts Berenguer y J. L. GonZÁlez CussaC, Compendio de Derecho penal. Parte general, 3. a ed., Valencia, Tirant lo Blanch, 2011, p. 403.

${ }_{95}$ Según constaba en el art. 70.3.1 podían durar hasta treinta años las penas de cárcel por aplicación de la pena superior en grado en los casos en los que corresponda, a lo que se añadía en el art. 76 la posibilidad de que la pena de cárcel a imponer alcanzase los veinticinco años si concurrieren delitos diferentes y uno de ellos estuviera castigado con pena de cárcel de hasta veinte años, o treinta años si uno de los delitos estuviese castigado con pena de cárcel superior a veinte años, aparte de que en los arts. 140 y 605 se preveía que esta pena durase veinticinco años para algunos casos de asesinato y en caso de delito contra el derecho de gentes, y en los arts. 473, 485 y 572 se establecía una pena de cárcel de hasta treinta años en caso de cometerse delitos de rebelión, si se matase a algún miembro de la casa real o en caso de que se perteneciese, actuase al servicio o colaborase con bandas armadas, organizaciones o grupos terroristas, y a causa de un atentado contra las personas se produjese alguna muerte, como queda fijado en el art. 572.

${ }_{96}$ Véase I. MuÑagorRi Laguía, «Reflexiones sobre la pena de prisión en el nuevo Código Penal: polifuncionalidad e incremento progresivo de la complejidad», Estudios penales y criminológicos, núm. 21 (1998), pp. 217-218.

97 Véase B. Mapelli Caffarena y J. Terradillos Basoco, Las consecuencias jurídicas del delito, op. cit., p. 71.

${ }^{8}$ Véase D. López Garrido y M. García Arán, El Código Penal de 1995 y la voluntad del legislador, Madrid, Eurojuris, 1996.

${ }_{99}$ En relación a las críticas de inconstitucionalidad del art. 78 del Código Penal véase también R. García Albero, «Libro I, título III, capítulo II (art. 78)», en G. Quintero OLI- 
Los dos últimos autores referidos criticaron la redacción que se le dio al art. 78 del Código Penal, pero celebraron que «afortunadamente, el nuevo Código Penal no acepta esta tendencia neorretribucionista», refiriéndose con ello al movimiento favorable al cumplimiento íntegro y efectivo de las penas, que estava en pleno auge. Sin embargo, otros penalistas vieron en dicho artículo la introducción de tal posibilidad. Así lo criticaron, por ejemplo, Gimbernat Ordeig ${ }^{100}$ y Muñagorri Laguía ${ }^{101}$. No pensaban lo mismo los miembros del grupo parlamentario del Partido Popular. A ellos no les parecía bastante restrictivo el art. 78 conforme estaba redactado, no veían que permitiese el cumplimiento efectivo de las penas, y es por ello que este grupo se negó a votar a favor de la aprobación del Código de 1995. Su rechazo al mismo fue ideológico, e ideológicas han sido parte de las reformas introducidas desde 2003 hasta nuestros días, después de las cuales aquél ha quedado irreconocible. Ha evolucionado a peor. En realidad más que reformas se han producido contrarreformas.

Parafraseando a Zugaldía Espinar, «he de reconocer lo acertado del dicho popular según el cual "otro vendrá que bueno me hará", o de la Ley de Murphy según la cual "cuando parece que ya nada puede ir peor, empeorará" ${ }^{102}$.Tenía razón Montesquieu cuando decía que «en todos o en casi todos los Estados de Europa las penas han disminuido o han aumentado a medida que se acercaban a la libertad o se alejaban de ella» ${ }^{103}$. Es obvio que en Europa en general y en el Estado español en particular se está produciendo un retroceso en las libertades, y también es innegable que dicho retroceso va acompañado de un endurecimiento de las penas hasta límites insospechados.

En 2003 se modificó el art. 76 para ampliar el límite máximo de la pena de cárcel, fijado, como en el Código Penal franquista, en cuarenta años, y se añadieron requisitos adicionales que dificultan — si no impiden, direc-

vares (dir.), Comentarios al Código Penal, vol. I. 5. ${ }^{a}$ ed., Cizur Menor, Thomson Aranzadi, 2006, pp. 621-622. El autor critica el artículo pero descarta que pretensiones de amparo tuviesen mucho éxito.

100 Véase E. Gimbernat Ordeig, «Crítica ideológica al nuevo Código Penal», El Mundo, 24 de mayo de 1996, p. 4.

101 Véase I. MuÑagorRi Laguía, «Reflexiones sobre la pena de prisión en el nuevo Código Penal: polifuncionalidad e incremento progresivo de la complejidad», op. cit., p. 213.

102 J. M. Zugaldía Espinar, «Contrarreforma penal (el annus horribilis de 2003) y el anteproyecto de reforma del Código Penal de 2006», en F. Bueno Arús, J. L. GuZMán DaLbora y A. SerRano Maíllo (coords.), Derecho penal y criminología como fundamento de la política criminal. Estudios en homenaje al profesor Alfonso Serrano Gómez, Madrid, Dykinson, 2006, pp. 1347-1382.

${ }_{103}$ Montesquieu, Del Espíritu de las Leyes, Madrid, Alianza, 2003, XII, 2. 
tamente- el acceso al tercer grado y a la libertad condicional, con lo cual los cuarenta años se cumplen de manera íntegra o prácticamente íntegra, y ello convierte a esta pena en perpetua, por mucho que este adjetivo no apareciese en el Código Penal. En concreto, en el art. 36 se introdujo un apartado segundo para exigir que, habiéndose impuesto una pena superior a cinco años, para acceder al tercer grado se hubiese cumplido al menos la mitad de la condena impuesta, y estar clasificado en tercer grado es requisito imprescindible para acceder a la libertad condicional, según se indica en el art. 90, y juntamente a éste se exigen otros requisitos nuevos que lo hacen más difícil todavía, sobre todo para determinados colectivos de internos: los condenados por delitos de terrorismo de la sección segunda del capítulo V del título XXII del libro II, o por delitos cometidos en el seno de organizaciones criminales, los cuales también están excluidos de la posibilidad de avanzar en la libertad condicional prevista en el art. 91. Además, si el art. 78 tal y como estaba redactado en el texto aprobado en 1995 ya fue muy criticado, más lo ha sido después de que las limitaciones allí previstas para acceder a los beneficios penitenciarios y a la libertad condicional se hayan extendido al tercer grado y a los permisos penitenciarios, además de que su aplicación dejó de ser facultativa y se convirtió en preceptiva para los supuestos $a$ ), b), c) y d) del art. 76.1, y en el caso de los colectivos de condenados indicados arriba sólo se permite la aplicación del régimen general — para lo cual ahora además de escucharse al Ministerio Fiscal también se ha de escuchar a Instituciones Penitenciarias y al resto de partes- cuando quede por cumplir una quinta parte del límite máximo de cumplimiento de la condena, en lo referente al acceso al tercer grado, y cuando quede por cumplir una octava parte para la libertad condicional.

Y aunque desde 2003 el encierro perpetuo se hizo un hueco en nuestro ordenamiento penal, los ciudadanos de a pie, esto es, la ciudadanía en general, o lo que es lo mismo, la mayoría de votantes, desconocían que fuese así porque en ningún artículo del Código Penal aparecía el término perpetua o cualquier otro equivalente, lo cual fue aprovechado por el Partido Popular para intentar ganar las elecciones, y las ganó. Este partido político, entonces en la oposición, incluyó en su programa electoral la reforma del Código Penal para incorporar la pena de prisión permanente revisable, y como partido en el gobierno, aunque le ha costado mucho tiempo hacerlo, ha cumplido su promesa. Lo veremos a continuación. 


\section{La inclusión de manera explícita de la pena de prisión perpetua}

El día que se abolieron las penas de encierro de por vida fue un día muy celebrado. Entonces se creyó que nunca más volverían a estar contempladas en un Código Penal, pues se suponía que con los años la tendencia sería suavizar el rigor penal y encontrar una pena, si no mejor, al menos no tan perjudicial como la de encierro en un establecimiento penitenciario. Pero no ha sido así.

La inclusión en el catálogo de penas del Código Penal de la llamada prisión permanente revisable ${ }^{104}$ se ha producido a través de la Ley Orgánica 1/2015, de 30 de marzo. De hecho, en lo que respecta a la Parte General de esta reforma, sin duda las novedades más relevantes son las que tienen que ver con el ámbito de las consecuencias jurídicas en general y con la introducción de la pena indicada en particular, enumerada en el nuevo art. 35 del Código Penal junto con las otras penas privativas de libertad.

Se prevé imponerla a los condenados por asesinatos especialmente graves, que están ahora definidos en el art. 140 del Código Penal, y que son aquellos cuyas víctimas son menores de dieciséis años o de personas especialmente vulnerables, los asesinatos subsiguientes a un delito contra la libertad sexual, los cometidos en el seno de una organización criminal y los reiterados o cometidos en serie. También se impondrá la pena de prisión permanente revisable, según figura en los arts. 485, 605 y 607, en caso de que se mate al rey o a la reina, o al príncipe o a la princesa de Asturias, o al jefe de un Estado extranjero, o a otra persona internacionalmente protegida por un tratado que se halle en España, o a alguno de los miembros de un grupo nacional, étnico, racial, religioso o determinado por la discapacidad de sus integrantes, si lo hace con la intención de destruir dicho grupo, o en caso de que con el mismo propósito se agreda

${ }^{104}$ Han criticado esta denominación M ABEL SOUTO, «Cadena perpetua y delitos contra la comunidad internacional (arts. 605.1, 607 y 607 bis)», en J. L. GoNZÁLEZ CUSSAC (dir.), Comentarios a la reforma penal de 2015, 2." ed., Valencia, Tirant lo Blanch, 2015, p. 1357; M. CANCIO Melí́, «La pena de cadena perpetua revisable ("prisión permanente revisable") en el proyecto de reforma del Código Penal», Diario La Ley, núm. 8.175 (octubre de 2013), p. 6; F. MUÑOZ CONDE, «Algunas reflexiones sobre la pena de prisión perpetua y otras sanciones similares a ella», en J. G. FERnÁNDEZ TERUELo (dir.), Estudios penales en homenaje al profesor Rodrigo Fabio Suárez Montes, Oviedo, Constitutio Criminalis Carolina, 2013, p. 448, y T. S. Vives ANTón, «La dignidad de todas las personas», El País, 30 de enero de 2015, p. 1. 
sexualmente a alguno de sus miembros o se produjera alguna de las lesiones previstas en el art. 149.

Debe tenerse en cuenta, asimismo, que la pena en cuestión no se impondrá sola, sino acompañada de otras penas y medidas accesorias. Según viene indicado en el art. 55 redactado por el apartado decimoquinto del artículo único de la Ley Orgánica 5/2010, aquélla se impondrá junto con la pena accesoria de inhabilitación absoluta durante el tiempo de la condena, aparte de que el juez también podrá disponer la inhabilitación especial para el ejercicio de la patria potestad, tutela, curatela, guarda o acogimiento, o bien la privación de la patria potestad, cuando estos derechos hubieren tenido relación directa con el delito cometido. Y eso no es todo, a los condenados a prisión permanente revisable por la comisión de uno o más delitos de asesinato se les impondrá además, y siempre, la medida de libertad vigilada, tal y como se ordena en el art. 140 bis. En los casos de homicidio, atentado contra la integridad y libertad sexuales y la integridad física, tal y como se prevé en el art. 57 según la redacción dada por el apartado decimoquinto del artículo único de la Ley Orgánica 5/2010, los jueces o tribunales, atendiendo a la gravedad de los hechos o al peligro que el delincuente represente, podrán acordar en sus sentencias la imposición de una o varias de las prohibiciones contempladas en el art. 48. En este supuesto, la pena de prisión y las prohibiciones acabadas de citar se cumplirán necesariamente por el condenado de forma simultánea, aunque una vez producida la excarcelación del reo, si es que se produce, esas prohibiciones todavía pueden mantenerse hasta diez años más. Consta, igualmente, que la aplicación de la pena prevista en el apartado segundo del art. 48 será obligatoria cuando los delitos contra la vida, la libertad e indemnidad sexuales o la integridad física arriba enumerados se cometan contra quien sea o haya sido el cónyuge, o sobre persona que esté o haya estado ligada al condenado por una análoga relación de afectividad aun sin convivencia, o sobre los descendientes, ascendientes o hermanos por naturaleza, adopción o afinidad, propios o del cónyuge o conviviente, o sobre los menores o personas con discapacidad necesitadas de especial protección que con él convivan o que se hallen sujetos a la potestad, tutela, curatela, acogimiento o guarda de hecho del cónyuge o conviviente, o sobre persona amparada en cualquier otra relación por la que se encuentre integrada en el núcleo de su convivencia familiar, así como sobre las personas que por su especial vulnerabilidad se encuentran sometidas a su custodia o guarda en centros públicos o privados.

Por lo que respecta a las prohibiciones del art. 48, en el núm. 1 de este artículo, redactado por el núm. 28 del artículo único de la Ley Orgá- 
nica $1 / 2015$, se contempla la privación del derecho a residir en determinados lugares o acudir a ellos, lo cual impide al penado residir o acudir al lugar en que haya cometido el delito, o a aquel en que resida la víctima o su familia, si fueren distintos; en el núm. 2 se prevé la prohibición de aproximarse a la víctima, o a aquellos de sus familiares u otras personas que determine el juez o tribunal, esto es, se le impide al penado acercarse a ellos, en cualquier lugar donde se encuentren, así como acercarse a su domicilio, a sus lugares de trabajo y a cualquier otro que sea frecuentado por ellos, quedando en suspenso, respecto de los hijos, el régimen de visitas, comunicación y estancia que, en su caso, se hubiere reconocido en sentencia civil hasta el total cumplimiento de esta pena, y en el núm. 3 está contemplada la prohibición de comunicarse con la víctima, o con aquellos de sus familiares u otras personas que determine el juez o tribunal, la cual impide al penado establecer con ellas, por cualquier medio de comunicación o medio informático o telemático, contacto escrito, verbal o visual. En el núm. 4 del art. 48 se advierte que el juez o tribunal podrá acordar que el control de estas medidas se realice a través de aquellos medios electrónicos que lo permitan.

Importa comentar ahora cuáles son las condiciones expresadas en el Código Penal para proceder a revisar la pena impuesta y, por tanto, a excarcelar al sujeto condenado a la pena que estamos analizando, y dichos requisitos aparecen recogidos en el art. 92, al cual se remite el art. 36. En el apartado segundo de este artículo se advierte que la revisión se realizará conforme a lo dispuesto en el nuevo art. 92, a tenor del cual la suspensión de la pena la decide el tribunal en caso de cumplirse una serie de requisitos, que son los siguientes: a) que el penado haya cumplido veinticinco años de su condena, $b$ ) que se encuentre clasificado en tercer grado y c) que el tribunal, a la vista de la personalidad del penado, sus antecedentes, las circunstancias del delito o total de delitos cometidos, la relevancia de los bienes jurídicos que podrían verse afectados por una reiteración en el delito, su conducta durante el cumplimiento de la o las penas, sus circunstancias familiares y sociales, y los efectos que quepa esperar de la propia suspensión de la ejecución y del cumplimiento de las medidas que fueren impuestas, pueda fundar, previa valoración de los informes de evolución remitidos por el centro penitenciario y por aquellos especialistas que el propio tribunal determine, la existencia de un pronóstico favorable de reinserción social.

En relación al primer requisito, el propio art. 36.2 advierte que será así sin perjuicio de lo dispuesto en el art. 78 bis para los casos regulados en 
el mismo, y es que en este artículo, que es otra de las novedades incorporadas por la Ley Orgánica 1/2015, se prevé que pueda exigirse el cumplimiento de hasta treinta y cinco años antes de poder proceder a estudiar la posibilidad de revisión de condena. En concreto, en el segundo apartado del art. 78 bis se dispone que se exigirá el cumplimiento de treinta años cuando el sujeto haya sido condenado por dos o más delitos y dos o más de ellos estén castigados con una pena de prisión permanente revisable, o bien uno de ellos esté castigado con una pena de prisión permanente revisable y el resto de penas impuestas sumen un total de veinticinco años o más. En el apartado tercero se establece un plazo mínimo de veintiocho años cuando el sujeto haya sido condenado por dos o más delitos referentes a organizaciones y grupos terroristas y delitos de terrorismo del capítulo VII del título XXII del libro II de este Código, o cometidos en el seno de organizaciones criminales, y uno de ellos esté castigado con pena de prisión permanente revisable y el resto de las penas impuestas sumen un total que exceda de cinco años, y cuando uno de los delitos cometidos esté castigado con una pena de prisión permanente revisable y el resto de las penas impuestas sumen un total que exceda de quince años. $Y$ en este mismo precepto el mínimo de pena a cumplir para poder estudiar la posibilidad de revisión asciende a los treinta y cinco años cuando el penado lo haya sido por varios delitos y dos o más de ellos estén castigados con una pena de prisión permanente revisable, o bien uno de ellos esté castigado con una pena de prisión permanente revisable y el resto de penas impuestas sumen un total de veinticinco años o más.

Por lo que se refiere a la clasificación en tercer grado, debe tenerse en cuenta lo previsto en el apartado tercero del art. 36. Aquí se dice que deberá ser autorizada por el tribunal previo pronóstico individualizado y favorable de reinserción social, oídos el Ministerio Fiscal e Instituciones Penitenciarias, y no podrá efectuarse: a) hasta el cumplimiento de veinte años de prisión efectiva, en el caso de que el penado lo hubiera sido por un delito del capítulo VII del título XXII del libro II de este Código; b) hasta el cumplimiento de quince años de prisión efectiva, en el resto de los casos. Sin embargo, también hay excepciones a estos plazos y también están contempladas en el art. 78 bis. En el primer apartado de este artículo se prevé que cuando el sujeto haya sido condenado por dos o más delitos, y, al menos, uno de ellos esté castigado por la ley con pena de prisión permanente revisable, la progresión a tercer grado requerirá del cumplimiento: a) de un mínimo de dieciocho años de prisión, cuando el penado lo haya sido por varios delitos, uno de ellos esté castigado con pena de prisión permanen- 
te revisable y el resto de las penas impuestas sumen un total que exceda de cinco años; b) de un mínimo de veinte años de prisión, cuando el penado lo haya sido por varios delitos, uno de ellos esté castigado con una pena de prisión permanente revisable y el resto de las penas impuestas sumen un total que exceda de quince años, o $c$ ) de un mínimo de veintidós años de prisión, cuando el penado lo haya sido por varios delitos y dos o más de ellos estén castigados con una pena de prisión permanente revisable, o bien uno de ellos esté castigado con una pena de prisión permanente revisable y el resto de penas impuestas sumen un total de veinticinco años o más. Y en el apartado tercero se añade que si se tratase de delitos referentes a organizaciones y grupos terroristas y delitos de terrorismo del capítulo VII del título XXII del libro II de este Código, o cometidos en el seno de organizaciones criminales, los límites mínimos de cumplimiento para el acceso al tercer grado de clasificación serán de veinticuatro años de prisión en los supuestos a que se refieren las letras $a$ ) y b) del apartado primero, y de treinta y dos años de prisión en el de la letra $c$ ) del apartado primero.

Por lo demás, parece lógico que se requiera la existencia de un pronóstico favorable de reinserción social, pero debería tenerse en cuenta que el paso por prisión, sobre todo y de manera especialmente intensa cuando el encierro se ha prolongado durante mucho tiempo, tiene efectos perjudiciales para la persona privada de libertad y que en sí mismos son un obstáculo para la resocialización. Se decidirá si existe un pronóstico favorable de reinserción social o si éste es desfavorable, pero no se tendrá en cuenta que es el propio encierro el que puede estar detrás de un progresivo empeoramiento de la conducta de un penado o de que éste haya perdido el contacto con la familia y dejado de recibir su apoyo, por poner un par de ejemplos.

Y si no fuese poco con los indicados, a los condenados por delitos referentes a organizaciones y grupos terroristas y delitos de terrorismo del capítulo VII del título XXII del libro II de este Código se les exigen otras condiciones, contempladas en el apartado segundo del art. 92. Aquí se requiere mostrar signos inequívocos de haber abandonado los fines y los medios de la actividad terrorista y colaborar activamente con las autoridades, bien para impedir la producción de otros delitos por parte de la organización o grupo terrorista, bien para atenuar los efectos de su delito, bien para la identificación, captura y procesamiento de responsables de delitos terroristas, para obtener pruebas o para impedir la actuación o el desarrollo de las organizaciones o asociaciones a las que haya pertenecido o con las que haya colaborado, lo que podrá acreditarse mediante una declaración expre- 
sa de repudio de sus actividades delictivas y de abandono de la violencia y una petición expresa de perdón a las víctimas de su delito, así como por los informes técnicos que acrediten que el preso está realmente desvinculado de la organización terrorista y del entorno y actividades de asociaciones y colectivos ilegales que la rodean y su colaboración con las autoridades. La exigencia de este requisito, además de que puede dar lugar a acusaciones falsas, en la práctica es un impedimento a la posibilidad de revisión de la condena y liberación de las personas condenadas a la pena indicada. Y por lo que se refiere al tema del arrepentimiento y el perdón, debe hacerse constar que estos elementos suelen identificarse con la voluntad de una justicia penal más humanizada y que de hecho se presentan como elementos (metaracionales) a través de los cuales se busca la reconciliación entre víctima y victimario, la creación de relaciones entre ambos o la reconstrucción de las existentes antes del hecho violento ${ }^{105}$. Esto en sí ya puede ser criticable, pues, como indica Carbonell Mateu, no se puede «hacer depender la concesión de la libertad de sentimientos y acciones morales que nada tienen que ver ni con la culpabilidad ni con la peligrosidad del sujeto» ${ }^{106}$. Pero es que, además, parece que lo que aquí se pretende es también, y sobre todo, obstaculizar la salida de la cárcel de dichas personas. Se trata de una estrategia al servicio de la retribución y la inocuización.

Teniendo en cuenta todos estos requisitos se entenderá por qué Cancio Meliá afirma que «el adjetivo "revisable" debería venir acompañado [...] por una precisión clarificadora como "siempre que el camello pase por el ojo de la aguja" ${ }^{107}$. Como apunta este catedrático de Derecho penal: «La decisión de la suspensión se diseña como una salida prácticamente excepcional, al acumularse una serie de requisitos de dificilísima concurrencia -máxime, tras un período de cumplimiento obligatorio ya muy prolongado- para que se pueda formular por el Tribunal un pronóstico positivo de inocuidad del penado» ${ }^{108}$.

Por esta y otras razones que sintetiza a la perfección Carbonell Mateu, la pena en cuestión es una pena inconstitucional. Dichas razones son las

105 A. BERISTAIn, Nueva criminología desde el Derecho penal y la victimología, Valencia, Tirant lo Blanch, 2000, pp. 79 y ss.

106 J. C. Carbonell Mateu, «Los proyectos de reforma del Código Penal: un retroceso histórico», Teoría y Derecho, núm. 14 (2013), p. 286, e íD., «Prisión permanente revisable I (arts. 33 y 35)», en J. L. GONZÁlez CuSSAC (dir.), Comentarios a la reforma penal de 2015,

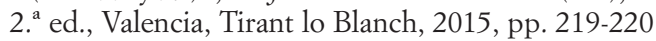

${ }_{107}$ M. CANCIO Melí́, «La pena de cadena perpetua revisable ("prisión permanente revisable”) en el proyecto de reforma del Código Penal», op. cit., p. 4.

${ }^{108}$ Ibid. 
siguientes: «Lo es por las condiciones de revisabilidad, en las que reina la incerteza y el decisionismo sin que en ningún caso quepa la suspensión obligatoria; lo es porque establece requisitos que resultan de imposible cumplimiento tras treinta y cinco años de vida penitenciaria; lo es por hacer depender la concesión de la libertad de sentimientos y acciones morales que nada tienen que ver ni con la culpabilidad ni con la peligrosidad del sujeto, y lo es por su clara contradicción con el principio de legalidad que impone el conocimiento potencial de las consecuencias que se derivarán de la comisión de un hecho delictivo en el momento de dicha comisión» ${ }^{109}$.

No son los citados los únicos expertos en Derecho penal que han tachado de inconstitucional la sanción que estamos comentando. Además de que catedráticos de treinta y tres universidades públicas españolas firmaron un manifiesto conjunto en contra ${ }^{110}$, una parte de los mismos y otros profesores titulares de Derecho penal han publicado artículos donde defienden esta postura ${ }^{111}$.

109 J. C. Carbonell Mateu, «Los proyectos de reforma del Código Penal: un retroceso histórico», op. cit., p. 286.

${ }^{110}$ Manifiesto de catedráticos de Derecho penal de treinta y tres universidades públicas españolas ante la grave situación que atraviesa la legislación sancionadora penal y administrativa en España. El manifiesto puede consultarse online en www.ub.edu/dpenal/recursos/ documents/btml (fecha de última consulta: 19 de octubre de 2015).

111 Además de los acabados de citar véanse M. ABEL Souto, «Cadena perpetua y delitos contra la comunidad internacional (arts. 605.1, 607 y 607 bis)», op. cit., pp. 1355-1366; M. AcAlÉ SÁncheZ, «Prisión permanente revisable: arts. 36 (3 y 4), 70.4, 76.1, 78 bis, 92, 136 y concordantes en la parte especial», en F. J. Álvarez GARCíA (dir.), Estudio crítico sobre el anteproyecto de reforma penal de 2012, Valencia, Tirant lo Blanch, 2013, pp. 179-200; F. J. Álvarez García, «Comparecencia para informar en relación con el proyecto de ley orgánica por la que se modifica la Ley Orgánica 10/1995, de 23 de noviembre, del Código Penal. Por acuerdo de la comisión de justicia», Diario de Sesiones del Congreso de los Diputados, núm. 503, 18 de febrero de 2014, pp. 10-22; J. DEL CARPIO Delgado, «La pena de prisión permanente en el anteproyecto de 2012 de reforma del Código Penal», Diario La Ley, núm. 8.004 (enero de 2013), pp. 1-31; M. GARCía ARÁN, «Comparecencia para informar en relación con el proyecto de ley orgánica por la que se modifica la Ley Orgánica 10/1995, de 23 de noviembre, del Código Penal. Por acuerdo de la comisión de justicia», Diario de Sesiones del Congreso de los Diputados, núm. 503, 18 de febrero de 2014, pp. 33-45; T. GonZÁLEZ CollanteS, «¿Sería inconstitucional la pena de prisión permanente revisable?», ReCrim, núm. 9 (2013), pp. 6-23; M. M. GONZÁLEZ TASCÓN, «Prisión perpetua: arts. 36 (3 y 4), 70, 76 y 78 bis CP», en F. J. Álvarez García (dir.), Estudio crítico sobre el anteproyecto de reforma penal de 2012, Valencia, Tirant lo Blanch, 2013, pp. 205-221; J. M. Lorenzo SALGADO, «Las penas privativas de libertad en el nuevo Código Penal español (especial referencia al arresto de fin de semana)», Estudios Penales y Criminológicos, núm. XX (1997), pp. 149-224; E. B. Marín de Espinosa y Ceballos y M. M. González Tascón, «Prisión perpetua (art. 36.3 y 4 CP)», en F. J. ÁlVVAREZ GARCía (dir.), Estudio crítico sobre el anteproyecto de reforma penal de 2012, Valencia, Tirant lo Blanch, 2013, pp. 201-204; F. MuÑoz ConDE, «Algunas reflexio- 
Otro aspecto a tener en cuenta es que el trato más humanitario previsto en el art. 91 del Código en relación a los septuagenarios, a los cuales se les puede avanzar la concesión de la libertad condicional siempre y cuando cumplan una serie de requisitos contemplados en el art. 90 - que son: encontrarse clasificado en tercer grado, haber observado buena conducta y haber satisfecho la responsabilidad civil derivada del delito en los supuestos y conforme a los criterios establecidos por los apartados 5 y 6 del art. 72 de la Ley Orgánica 1/1979, de 26 de septiembre, General Penitenciaria- ${ }^{112}$, no regiría en el caso de que la pena impuesta fuese la de prisión permanente revisable. Encontramos aquí una nueva manifestación de la prevalencia del principio de seguridad sobre el de humanidad.

\section{REFLEXIÓN FINAL: EL POR QUÉ DEL RESTABLECIMIENTO DE LA PENA DE PRISIÓN PERPETUA}

El establecimiento de la pena de prisión permanente revisable implica un retroceso histórico, retrotraernos a los Códigos Penales del siglo XIX, y no atiende a razones de necesidad, pues el Código Penal español ya era con anterioridad a la introducción de la última reforma uno de los más represivos de toda Europa, y ello a pesar de que España es uno de los países con los porcentajes de criminalidad más bajos. Es más, a pesar de ser cierto que durante muchos años, demasiados, hemos sufrido la lacra del terrorismo, en 2011 ETA anunció un alto al fuego permanente, general y verificable, y desde entonces no ha vuelto a atentar. Precisamente por esto Carbonell Mateu critica no sólo la falta de necesidad de la reforma, sino también la inoportunidad de la misma. En palabras de este catedrático de Derecho penal: «Justamente cuando el terrorismo ha dejado de ser el primer motivo de preocupación de los ciudadanos, cuando el problema prácticamente ha desaparecido, cuando la banda se encuentra técnicamente

nes sobre la pena de prisión perpetua y otras sanciones similares a ella», op. cit., pp. 447-457; M. ROIG TORRES, «La cadena perpetua: los modelos inglés y alemán. Análisis de la STEDH de 9 de julio de 2013. La prisión permanente revisable a examen», Cuadernos de Política Criminal, núm. 111 (2013), pp. 97-144; T. S. Vives ANTÓN, «La dignidad de todas las personas», op. cit., y J. M. ZugALDÍA ESPINAR, «Comparecencia para informar en relación con el proyecto de ley orgánica por la que se modifica la Ley Orgánica 10/1995, de 23 de noviembre, del Código Penal. Por acuerdo de la comisión de justicia», Diario de Sesiones del Congreso de los Diputados, núm. 503, 18 de febrero de 2014, pp. 22-33.

${ }_{112}$ Los arts. 90 y 91 del Código Penal se han visto afectados por la reforma introducida en el Código Penal por la Ley Orgánica 1/2015, de 30 de marzo. 
"en tregua permanente irreversible" y en la práctica extinguida, cuando lo que parece necesario es abordar una política criminal que permita asegurar dicha extinción y adecuar las penas que se elevaron con motivo del incremento del terrorismo a una situación diferente, cuando probablemente se imponga revisar criterios de ejecución penitenciaria y buscar la integración de los penados en la sociedad, es cuando al gobierno de España le antoja oportuno elevar aún más las penas, introducir la cadena perpetua y someter su ejecución a una rigidez que significar dar por supuesta la permanencia de una peligrosidad que parece, por el contrario, desaparecida. Debe destacarse, por ello, la tremenda inoportunidad de la introducción de una pena» ${ }^{113}$.

La filosofía que emana de la profunda revisión del sistema de consecuencias penales en general y de la introducción de la cadena perpetua revisable en particular no es otra que el puro populismo punitivo ${ }^{114}$. La expresión «populismo punitivo» fue acuñada por Bottoms en 1995 para

113 J. C. Carbonell Mateu, «Los proyectos de reforma del Código Penal: un retroceso histórico», op. cit., pp. 284-285, e íD., «Prisión permanente revisable I (arts. 33 y 35)», op. cit., pp. 214-215.

114 M. ABEL Souto, «Cadena perpetua y delitos contra la comunidad internacional (arts. 605.1, 607 y 607 bis)», op. cit., p. 1358; F. J. ÁlvAREZ GARCÍA, «Comparecencia para informar en relación con el proyecto de ley orgánica por la que se modifica la Ley Orgánica 10/1995, de 23 de noviembre, del Código Penal. Por acuerdo de la comisión de justicia», op. cit., pp. 20-21; M. CANCIO MELIÁ, «La pena de cadena perpetua revisable ("prisión permanente revisable") en el proyecto de reforma del Código Penal», op. cit., p. 7; M. ROIG TORRES, «La cadena perpetua: los modelos inglés y alemán. Análisis de la STEDH de 9 de julio de 2013. La prisión permanente revisable a examen», op. cit., p. 141; M. GARCÍA ARÁN, «Comparecencia para informar en relación con el proyecto de ley orgánica por la que se modifica la Ley Orgánica 10/1995, de 23 de noviembre, del Código Penal. Por acuerdo de la comisión de justicia», op. cit., p. 33, y T. GONZÁLEZ COLLANTES, «¿Sería inconstitucional la pena de prisión permanente revisable?», op. cit., pp. 6-23. Sobre la nueva tendencia político-criminal véanse también M. Aranda Ocaña, G. Chaves Castillo, M. Moreno Aldea, J. D. Posada Segura, C. Rivas Trullols e I. Rivera Beiras, El populismo punitivo. Análisis de las reformas y contrarreformas del sistema penal en España (1995-2005), Barcelona, Observatorio del Sistema Penal y los Derechos Humanos de la Universidad de Barcelona, 2005, 170 pp.; E. LARRAURI PIJOAn, «Populismo punitivo... y cómo resistirlo», Jueces para la Democracia, núm. 55 (2006), pp. 15-22; G. Quintero Olivares, «La derrota de la política criminal y del Derecho penal de nuestro tiempo», IUS, núm. 19 (2007), pp. 46-72; J. O. Sotomayor Acosta, «¿El Derecho penal garantista en retirada?», Revista Penal, núm. 21 (2008), pp. 148-164; M. MARTínEZ, «Populismo punitivo, mayorías y víctimas», Nomos, núm. 2 (2008), pp. 183-199; G. LandROve Díaz, «Una cierta política criminal», en J. C. Carbonell Mateu, J. L. González Cussac, E. Orts Berenguer y M. L. Cuerda Arnau (coords.), Constitución, derechos fundamentales y sistema penal (semblanzas y estudios con motivo del setenta aniversario del profesor Tomás Salvador Vives Antón), vol. 2, Valencia, Tirant lo Blanch, 2009, pp. 1079-1088; E. OrTS BERENGUER, «La deriva actual del Derecho penal en España», ReCrim, núm. 2 (2009), pp. 260-264, y J. M. Silva SÁncheZ, «El populismo punitivo», Escritura Pública, núm. 55 (2009), p. 15. 
hacer referencia a la utilización del Derecho penal por parte de la clase política con el objetivo de obtener réditos electorales defendiendo una política criminal basada en la idea de que a través del incremento del punitivismo, de la «mano dura», de la «tolerancia cero», se consigue reducir la delincuencia ${ }^{115}$, sin importar que existan estudios que contradicen esta teoría ni tampoco que con ello se socaven principios fundamentales propios de un Estado de Derecho, abandonándose, además, el discurso de la resocialización y priorizándose la pura retribución y la incapacitación. De hecho, el uso populista del Derecho penal acentúa la estigmatización del delincuente como un enemigo y la creencia de que como tal ha de ser tratado, de que se le debe eliminar. Las leyes penales populistas se convierten en Derecho penal del enemigo. Como indica Hassemer: «Violencia, riesgo y amenaza constituyen hoy fenómenos centrales de la percepción social. La seguridad ciudadana hace su carrera como bien jurídico y alimenta una creciente industria de la seguridad [...] La sociedad, amenazada por la violencia y el delito, se ve puesta contra la pared. En su percepción, ella no se puede dar el lujo de un Derecho penal entendido como protección de la libertad, como "Carta Magna del delincuente", lo necesita como "Carta Magna del ciudadano", como arsenal de lucha efectiva contra el delito y represión de la violencia. El delincuente se convierte tendencialmente en enemigo y el Derecho penal en "Derecho penal del enemigo" ${ }^{116}$.

También Vives Antón critica esta tendencia, y lo hace con estas palabras: «Existe una suerte de "reflejo condicionado" de la opinión pública en el ámbito del Derecho punitivo que se manifiesta en la reacción ante los atentados más frecuentes, si revisten alguna gravedad: frente a ellos surge, inexorablemente, la idea de elevar las penas, de la que algunas veces se hace eco el legislador. Pero por ese camino pronto se rebasa el límite de la justicia. Frente a la tendencia a adoptar una intervención penal máxima se propugnaba entonces atenerse al principio de intervención mínima, esto es, a mantenerse en el espacio propugnado desde el Derecho penal liberal. Esa apelación al liberalismo, que entonces fue pacíficamente aceptada, podrá resultar hoy sorprendente a quienes han olvidado que los derechos constitucionales liberales pertenecen a la esencia misma del proceso democrático o, dicho de otro modo, que más allá

115 A. Botтoms, «The philosophy and politics of punishment and sentencing», en C. Clarkson y R. Morgan (eds.), The Politics of Sentencing Reform, Oxford, Clarendon Press, 1995, p. 39.

116 W. Hassemer, Crítica al Derecho penal de hoy, traducción de P. S. Ziffer, Buenos Aires, Ad Hoc, 2003, p. 52. 
de ellos (que constituyen el núcleo de lo que llamamos Estado de Derecho) no hay ninguna democracia posible. Como ha razonado Habermas hasta la saciedad, democracia y Estado de Derecho se autoimplican, de modo que no puede hablarse de la una sin el otro, y cuando por el recurso irracional a la pena se menoscaban las exigencias del Estado de Derecho se está menoscabando, a la vez, el sistema democrático y optando por un Estado autoritario» ${ }^{117}$.

A lo anterior, este ilustre penalista añade lo siguiente: «La demanda social es una lógica expresión de solidaridad ante el dolor de algunas víctimas de conductas execrables, frente a las que brotan sentimientos de repulsa y de venganza fácilmente manipulables por poderes fácticos. Pero la libertad no es un mercado en el que el legislador tenga como objetivo satisfacer esas demandas. Es más, el Estado surge como una institución que se impone a esos sentimientos y deseos y sustituye la reacción impulsiva de los afectados directa o indirectamente por el delito, por una respuesta racional. Esa respuesta racional de la pena parte de la idea de que la libertad, incluso la libertad del imputado, ha de ser sacrificada lo menos posible; por eso no deberían poder imponerse más penas que las estricta y absolutamente necesarias, según expresaran las primeras grandes declaraciones de derechos y exige la Constitución Española de 1978, en virtud del principio de proporcionalidad» ${ }^{118}$. Si el Estado renuncia a ello deja de ser un Estado de Derecho o, como advierte Vives Antón: «Si el Estado al configurar la pena procediera según los impulsos que nacen de las víctimas y de su entorno social, acabaría convirtiéndose no en el Estado de la justicia, sino en el de la venganza; esto es, en el Estado totalitario que propugnara Carl Schmitt» ${ }^{119}$.

Desgraciadamente ninguna de estas críticas parece importar, como tampoco importan las investigaciones sobre los efectos que el encarcelamiento de larga duración produce en las personas presas. Sólo cabe preguntarse si, visto lo visto, todavía podemos seguir definiendo el español como un Estado de Derecho y afirmando que tiene a la dignidad como fundamento del orden político y de la paz social.

117 T. Vives AnTón, Reflexiones jurídico-politicas a propósito de un anteproyecto de Código Penal, ¿estado democrático o estado autoritario?, Valencia, Tirant lo Blanch, 2008, p. 3.

${ }_{118}$ Ibid.

${ }^{119}$ Ibid. 


\section{BIBLIOGRAFÍA}

Abel Souto, M., «Cadena perpetua y delitos contra la comunidad internacional (arts. 605.1, 607 y 607 bis)», en J. L. González CussaC (dir.), Comentarios a la reforma penal de 2015, 2. ${ }^{\text {e }}$ ed., Valencia, Tirant lo Blanch, 2015.

ACAlÉ SÁnCHEZ, M., «Prisión permanente revisable: arts. 36 (3 y 4), 70.4, 76.1, 78 bis, 92, 136 y concordantes en la parte especial», en F. J. Álvarez García (dir.), Estudio crítico sobre el anteproyecto de reforma penal de 2012, Valencia, Tirant lo Blanch, 2013.

Álvarez García, F. J., «Comparecencia para informar en relación con el proyecto de ley orgánica por la que se modifica la Ley Orgánica 10/1995, de 23 de noviembre, del Código Penal. Por acuerdo de la comisión de justicia», Diario de Sesiones del Congreso de los Diputados, núm. 503, 18 de febrero de 2014.

Aranda Ocaña, M.; Chaves Castillo, G.; Moreno Aldea, M.; Posada SeguRa, J. D.; Rivas Trullols, C., y Rivera BeIras, I., El populismo punitivo. Análisis de las reformas y contrarreformas del sistema penal en España (1995-2005), Barcelona, Observatorio del Sistema Penal y los Derechos Humanos de la Universidad de Barcelona, 2005.

BARBERo SANTOS, M., «La pena de muerte, problema actual», en Estudios de Criminología y Derecho Penal, Valladolid, Universidad de Valladolid, 1972.

- Política y Derecho penal en España, 1. a ed., Madrid, Tucar, 1977.

Beristain, A., Nueva criminología desde el Derecho penal y la victimología, Valencia, Tirant lo Blanch, 2000.

Bernal y Gaipo, B. M., «La pena de muerte en España», en C. García Valdés (dir.), La historia de la prisión, teorías economicistas. Crítica, Madrid, Edisofer, 1997.

CANCIO Melí́, M., «La pena de cadena perpetua ("prisión permanente revisable”) en el proyecto de reforma del Código Penal», Diario La Ley, núm. 8.175 (22 de octubre de 2013).

Carbonell Mateu, J. C., «Los proyectos de reforma del Código Penal: un retroceso histórico», Teoría y Derecho, núm. 14 (2013).

— «Prisión permanente revisable I (arts. 33 y 35)», en J. L. GonzÁlez CusSAC (dir.), Comentarios a la reforma penal de 2015, 2. ${ }^{\text {e }}$ ed., Valencia, Tirant lo Blanch, 2015.

Carpio Delgado, J., «La pena de prisión permanente en el Anteproyecto de 2012 de reforma del Código Penal», Diario La Ley, núm. 8.004 (18 de enero de 2013).

CARreras, A., Estadísticas históricas de España: siglos XIX-XX, Madrid, Fundación Banco Exterior, 1989.

Casabó Ruiz, J. R., «Estudio Preliminar», en El Anteproyecto de Código Penal de 1938 de FET y de las JONS, Murcia, Departamento de Derecho Penal y Secretariado de Publicaciones de la Universidad de Murcia, 1978. 
- El Código Penal de 1822, tesis doctoral, Valencia, Facultad de Derecho de la Universidad de Valencia, 1968.

Cobo del Rosal, M., y Vives Antón, T. S., Derecho Penal. Parte General, 5. ${ }^{\text {ed }}$ ed. actualizada por M. L. Cuerda Arnau y M. Quintanar, Valencia, Tirant lo Blanch, 1999.

Cuello Calón, E., Derecho Penal. Parte General, 3. ed. considerablemente aumentada y adaptada al Código Penal de 1932, Barcelona, Bosch, 1935.

- Penología, las penas y las medidas de seguridad. Su ejecución, Madrid, Reus, 1920.

Foucault, M., Vigilar y castigar, traducción al castellano de A. Garzón del Camino, 9. 'a ed., Madrid, Siglo XXI de España, 1994.

García Albero, R., «Libro I, título III, capítulo II (art. 78)», en G. Quintero Olivares (dir.), Comentarios al Código Penal, vol. I, 5. a ed., Cizur Menor, Thomson Aranzadi, 2006.

GARCíA ARÁN, M., «Comparecencia para informar en relación con el proyecto de ley orgánica por la que se modifica la Ley Orgánica 10/1995, de 23 de noviembre, del Código Penal. Por acuerdo de la comisión de justicia», Diario de Sesiones del Congreso de los Diputados, núm. 503, 18 de febrero de 2014.

Garrido Guzmán, L., Manual de ciencia penitenciaria, Madrid, Edersa, 1983.

Gimbernat Ordeig, E., «Crítica ideológica al nuevo Código Penal», El Mundo, 24 de mayo de 1996.

GonzÁlez Collantes, T., «¿Sería inconstitucional la pena de prisión permanente revisable?», ReCrim, núm. 9 (2013).

- «Las prisiones en el contexto de la Guerra Civil española, el franquismo y la transición a la democracia», E-Legal History Review, núm. 19 (2015).

- «Auge y crisis de la resocialización. Crisis y auge de la pena de prisión», Cuadernos de Política Criminal, núm. 115, época II (2015).

GonzÁlez TAscón, M. M., «Prisión perpetua: arts. 36 (3 y 4), 70, 76 y 78 bis CP», en F. J. Álvarez García (dir.), Estudio crítico sobre el anteproyecto de reforma penal de 2012, Valencia, Tirant lo Blanch, 2013.

Groizard y Gómez de la Serna, A., El Código Penal de 1870 concordado y comentado, vol. I, 2. a ed. corregida y aumentada, Madrid, Establecimiento tipográfico de los Hijos de J. A. García, 1902.

Hassemer, W., Crítica al Derecho penal de hoy, traducción de P. S. Ziffer, Buenos Aires, Ad Hoc, 2003.

Herrero Herrero, C., España penal y penitenciaria (bistoria y actualidad), Madrid, Dirección General de la Policía, División de Formación y Perfeccionamiento, Instituto de Estudios de la Policía, 1985.

Jaramillo García, A., Novísimo Código Penal comentado y cotejado con el de 1870, vol. I, libro I, Salamanca, Imprenta de Silvestre Ferreira, 1928. 
Jiménez de Asua, L., y Antón Oneca, J., Derecho penal conforme al Código Penal de 1928, Madrid, Reus, 1929.

Landrove Díaz, G., «Una cierta política criminal», en J. C. Carbonell Mateu, J. L. González Cussac, E. Orts Berenguer y M. L. Cuerda Arnau (coords.), Constitución, derechos fundamentales y sistema penal (semblanzas y estudios con motivo del setenta aniversario del profesor Tomás Salvador Vives Antón), vol. 2, Valencia, Tirant lo Blanch, 2009.

Langle Rubio, E., Código Penal de 17 de junio de 1870, Madrid, Hijos de Reus Editores, 1915.

Larrauri Pijoan, E., «Populismo punitivo... y cómo resistirlo», Jueces para la Democracia, núm. 55 (2006).

Leganés Gómez, S., La evolución de la clasificación penitenciaria, Madrid, Ministerio del Interior, 2005.

López Garrido, D., y García Arán, M., El Código Penal de 1995 y la voluntad del legislador, Madrid, Eurojuris, 1996.

Lorenzo Salgado, J. M., «Las penas privativas de libertad en el nuevo Código Penal español (especial referencia al arresto de fin de semana)», Estudios Penales y Criminológicos, núm. XX (1997).

LuRRA, Rebelión en las cárceles, Donostia-San Sebastián, Hordago, 1978.

Manifiesto de catedráticos de Derecho penal de treinta y tres universidades públicas españolas ante la grave situación que atraviesa la legislación sancionadora penal y administrativa en España, 21 de enero de 2015. Disponible online en www. ub.edu/dpenal/recursos/documents/btml.

Mapelli Caffarena, B., y Terradillos Basoco, J., Las consecuencias jurídicas del delito, 3. ${ }^{a}$ ed., Madrid, Civitas, 1996.

Marín de Espinosa y Ceballos, E. B., y González Tascón, M. M., «Prisión perpetua (art. 36.3 y 4 CP)», en F. J. Álvarez GARCía (dir.), Estudio crítico sobre el anteproyecto de reforma penal de 2012, Valencia, Tirant lo Blanch, 2013.

Martínez, M., «Populismo punitivo, mayorías y víctimas», Nomos, núm. 2 (2008).

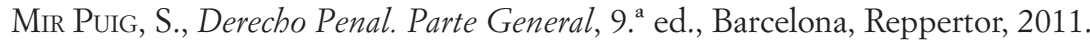

Mommsen, T., El Derecho penal romano, vol. II, traducción de P. Dorado Montero, Madrid, Jiménez Gil Editor, 1999.

Montesquieu, Del Espiritu de las Leyes, Madrid, Alianza, 2003.

Moro Rodríguez, A., «La prisión en la Roma antigua», Revista de la Escuela de Estudios Penitenciarios, núm. 19 (1946).

Muñagorri Laguía, I., «Reflexiones sobre la pena de prisión en el nuevo Código Penal: polifuncionalidad e incremento progresivo de la complejidad», Estudios Penales y Criminológicos, núm. 21 (1998).

MuÑoz Conde, F., «Algunas reflexiones sobre la pena de prisión perpetua y otras sanciones similares a ella», en J. G. FERnÁNDEZ TERUELo (dir.), Estudios penales 
en bomenaje al profesor Rodrigo Fabio Suárez Montes, Oviedo, Constitutio Criminalis Carolina, 2013.

Orts Berenguer, E., «La deriva actual del Derecho penal en España», ReCrim, núm. 2 (2009).

Orts Berenguer, E., y González Cussac, J. L., Compendio de Derecho Penal. Parte General, 3. a ed., Valencia, Tirant lo Blanch, 2011.

Pacheco, J. F., El Código Penal concordado y comentado, vol. I, Madrid, Imprenta de la Viuda de Perinat y Compañía, 1856.

Quintero Olivares, G., «La derrota de la política criminal y del Derecho penal de nuestro tiempo», IUS, núm. 19 (2007).

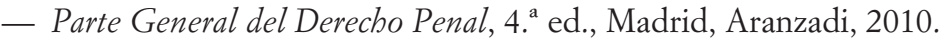

Rodríguez Devesa, J. M. a , y Serrano Gómez, A., Derecho Penal español. Parte General, 18. ${ }^{a}$ ed., Madrid, Dykinson, 1995.

Roig Torres, M., «La cadena perpetua: los modelos inglés y alemán. Análisis de la STEDH de 9 de julio de 2013. La prisión permanente revisable a examen», Cuadernos de Política Criminal, núm. 111 (2013).

San Martín Losada, L., Algunas observaciones sobre el nuevo Código Penal, Madrid, Publicaciones de la Real Academia de Jurisprudencia y LegislaciónReus, 1929.

- El Código Penal de 1928, su estudio y comparación con el de 1870, prólogo de R. García del Valle, Madrid, Imprenta Clásica Española, 1928.

Serrano Butragueño, I., Código Penal de 1995. Comentarios y jurisprudencia, Granada, Comares, 1999.

Silva Sánchez, J. M., «El populismo punitivo», Escritura Pública, núm. 55 (2009).

Sotomayor Acosta, J. O., «¿El Derecho penal garantista en retirada?», Revista Penal, núm. 21 (2008).

Téllez Aguilera, A., Los sistemas penitenciarios y sus prisiones. Derecho y realidad, Madrid, Edisofer, 1998.

Vicente y Caravantes, J., Código Penal reformado comentado novísimamente, Madrid-Santiago, Librerías de Don Ángel Calleja, 1851.

Vives Antón, T. S., Reflexiones jurídico-políticas a propósito de un anteproyecto de Código Penal, ¿estado democrático o estado autoritario?, Valencia, Tirant lo Blanch, 2008.

— «La dignidad de todas las personas», El País, 30 de enero de 2015.

Vizmanos, T. M., y Álvarez Martínez, C., Comentarios al Código Penal, vol. I, Madrid, Establecimiento Tipográfico de J. González y A. Vicente, 1848.

Von Hentig, H., La pena II, las formas modernas de aparición, traducción al castellano y notas de J. M. ${ }^{a}$ Rodríguez Devesa, Madrid, Espasa Calpe, 1968.

Zugaldía Espinar, J. M., «Comparecencia para informar en relación con el proyecto de ley orgánica por la que se modifica la Ley Orgánica 10/1995, de 23 
de noviembre, del Código Penal. Por acuerdo de la comisión de justicia», Diario de Sesiones del Congreso de los Diputados, núm. 503, 18 de febrero de 2014.

- «Contrarreforma penal (el annus horribilis de 2003) y el anteproyecto de reforma del Código Penal de 2006», en F. Bueno Arús, J. L. Guzmán Dalbora y A. SeRRANo Maíllo (coords.), Derecho penal y criminología como fundamento de la política criminal. Estudios en homenaje al profesor Alfonso Serrano Gómez, Madrid, Dykinson, 2006. 